\title{
Chemical ionization quadrupole mass spectrometer with an electrical discharge ion source for atmospheric trace gas measurement
}

\author{
Philipp G. Eger ${ }^{1}$, Frank Helleis ${ }^{2}$, Gerhard Schuster ${ }^{1}$, Gavin J. Phillips ${ }^{1,2}$, Jos Lelieveld ${ }^{1}$, and John N. Crowley ${ }^{1}$ \\ ${ }^{1}$ Atmospheric Chemistry Department, Max-Planck-Institut für Chemie, 55128 Mainz, Germany \\ ${ }^{2}$ Department of Natural Sciences, University of Chester, Chester CH2 4NU, UK
}

Correspondence: John N. Crowley (john.crowley@mpic.de)

Received: 6 December 2018 - Discussion started: 19 December 2018

Revised: 20 February 2019 - Accepted: 12 March 2019 - Published: 26 March 2019

\begin{abstract}
We present a chemical ionization quadrupole mass spectrometer (CI-QMS) with a radio-frequency (RF) discharge ion source through $\mathrm{N}_{2} / \mathrm{CH}_{3} \mathrm{I}$ as a source of primary ions. In addition to the expected detection of PAN, peracetic acid (PAA) and $\mathrm{ClNO}_{2}$ through well-established ion-molecule reactions with $\mathrm{I}^{-}$and its water cluster, the instrument is also sensitive to $\mathrm{SO}_{2}, \mathrm{HCl}$ and acetic acid $\left(\mathrm{CH}_{3} \mathrm{C}(\mathrm{O}) \mathrm{OH}\right)$ through additional ion chemistry unique to our ion source. We present ionization schemes for detection of $\mathrm{SO}_{2}, \mathrm{HCl}$ and acetic acid along with illustrative datasets from three different field campaigns underlining the potential of the CI-QMS with an RF discharge ion source as an alternative to ${ }^{210} \mathrm{Po}$. The additional sensitivity to $\mathrm{SO}_{2}$ and $\mathrm{HCl}$ makes the CI-QMS suitable for investigating the role of sulfur and chlorine chemistry in the polluted marine and coastal boundary layer.
\end{abstract}

\section{Introduction}

Chemical ionization mass spectrometry using iodide anions (commonly referred to as I-CIMS) is a widely used technique to measure various atmospheric trace gases with a high temporal resolution and low detection limit. The potential of I-CIMS for atmospheric trace gas measurement was established in laboratory studies (Huey et al., 1995) on chlorine nitrate $\left(\mathrm{ClONO}_{2}\right)$, which plays a central role in polar stratospheric $\mathrm{O}_{3}$ depletion (Molina et al., 1987), and dinitrogen pentoxide $\left(\mathrm{N}_{2} \mathrm{O}_{5}\right)$, which, through its heterogeneous hydrolysis on cloud droplets and aerosols, acts as a sink of gas-phase $\mathrm{NO}_{x}\left(\mathrm{NO}+\mathrm{NO}_{2}\right)$ (Lelieveld and Crutzen, 1990; Dentener and Crutzen, 1993). The first applications of I-CIMS for monitoring atmospheric composition were for measurement of $\mathrm{N}_{2} \mathrm{O}_{5}$, peroxyacyl nitric anhydride (PAN, $\mathrm{CH}_{3} \mathrm{C}(\mathrm{O}) \mathrm{O}_{2} \mathrm{NO}_{2}$ ) and other peroxycarboxylic nitric anhydrides (Huey, 2007). Since then it has been recognized that several classes of organic and inorganic trace gases can be detected sensitively by I-CIMS including organic and inorganic acids, organic nitrates, halogen nitrates and dihalogens (Phillips et al., 2013; Lee et al., 2014; Neuman et al., 2016; Priestley et al., 2018). Our instrument has previously been deployed with a radioactive ion source $\left({ }^{210} \mathrm{Po}\right)$ to investigate the atmospheric chemistry of nitryl chloride $\left(\mathrm{ClNO}_{2}\right)$, PAN and peracetic acid $\left(\mathrm{PAA}, \mathrm{CH}_{3} \mathrm{C}(\mathrm{O}) \mathrm{OOH}\right)$ (Phillips et al., 2012, 2013, 2016; Crowley et al., 2018).

PAN (and other peroxycarboxylic nitric anhydrides) are formed in the atmosphere via the reaction of $\mathrm{NO}_{2}$ with peroxyacyl radicals $\left(\mathrm{RC}(\mathrm{O}) \mathrm{O}_{2}\right)$ generated during the photo-oxidation of volatile organic compounds. Slusher et al. (2004) reported the first detection of PAN, PPN (peroxypropionic nitric anhydride), MPAN (peroxymethacrylic nitric anhydride) and PiBN (peroxyisobutyric nitric anhydride) using thermal decomposition chemical ionization mass spectrometry (TD-CIMS) with iodide ions. The most abundant, PAN, is of great importance owing to its role in transportation of $\mathrm{NO}_{2}$ from source regions to remote areas (Moxim et al., 1996). The detection of PAN and its analogues via I-CIMS requires thermal dissociation (generally at temperatures close to $100^{\circ} \mathrm{C}$ ) to the peroxy radical, which then reacts with $\mathrm{I}^{-}$primary ions to form the carboxylate anion, which is then detected. Compared to gas chromatographic meth- 
ods for detection of peroxycarboxylic nitric anhydrides, the I-CIMS technique allows faster measurements with comparable sensitivity and selectivity (Slusher et al., 2004; Roiger et al., 2011), enabling eddy covariance flux measurements (Turnipseed et al., 2006; Wolfe et al., 2009). Although the bond dissociation energy of the peroxycarboxylic nitric anhydrides is similar, Zheng et al. (2011) report lower sensitivity for APAN (peroxyacrylic nitric anhydride), PiBN, PnBN (peroxy-n-butyric nitric anhydride) and CPAN (peroxycrotonyl nitric anhydride) and Mielke and Osthoff (2012) report lower sensitivity for MPAN compared to PPN and PAN. Peroxycarboxylic nitric anhydrides have been measured using I-CIMS in various locations including boreal forests (Phillips et al., 2013), pine forests (Turnipseed et al., 2006; Wolfe et al., 2009), urban areas (Slusher et al., 2004; LaFranchi et al., 2009; Wang et al., 2017) and the Arctic (Roiger et al., 2011).

Detection of PAA by I-CIMS was reported by Phillips et al. (2013), who performed the first combined measurement of PAN and PAA in a boreal forest in Finland. PAA acts as a significant sink for $\mathrm{CH}_{3} \mathrm{C}(\mathrm{O}) \mathrm{O}_{2}$ and $\mathrm{HO}_{2}$ under low$\mathrm{NO}_{x}$ conditions and can compete with PAN formation, especially at high temperatures (Crowley et al., 2018). As for PAN, PAA was detected as the acetate anion at a mass-tocharge ratio $(m / z)$ of 59. Unlike other TD-CIMS instruments that describe an absence of a residual signal when NO is added to the inlet (e.g. Warneke et al., 2016), the I-CIMS deployed by Phillips et al. (2013) and the instrument presented in this study are very sensitive to PAA at $m / z$ 59. Furgeson et al. (2011) also describe an interference at $m / z 59$ that is not titrated by NO and suggest detection of PAA, which is produced in their photochemical source used for PAN generation. In addition, Veres et al. (2015) report a very similar mechanism to PAA detection for the detection of pernitric acid (PNA). Differences in the sensitivities of various I-CIMS instruments to PAA at $m / z 59$ are likely to be associated with different de-clustering potentials. At $m / z 59$, the I-CIMS deployed by Phillips et al. (2013) was insensitive to acetic acid. A wide range of organic acids can be detected as an $\mathrm{I}^{-}$cluster, with the parent molecule (Le Breton et al., 2012; Lee et al., 2014) using time-of-flight mass spectrometers (I-CIMS-TOF), which have a high mass resolution and exploit the iodine mass defect for the identification of the elemental composition of the organic trace gases detected.

$\mathrm{ClNO}_{2}$ is formed in the heterogeneous reaction of $\mathrm{N}_{2} \mathrm{O}_{5}$ on chloride-containing particles and surfaces during the night (Behnke et al., 1997). The daytime photolysis of $\mathrm{ClNO}_{2}$ results in the release of chlorine atoms, which enhance oxidation rates of organic trace gases, especially during early morning hours (Phillips et al., 2012; Riedel et al., 2012). Nitryl chloride has been observed by I-CIMS as $\mathrm{ICINO}_{2}^{-}$and $\mathrm{ICl}^{-}$in the polluted marine boundary layer (Osthoff et al., 2008; Riedel et al., 2012) close to the coast, for example, in Hong Kong (Wang et al., 2016) and London (Bannan et al., 2015) but also inland in continental North America (Thorn- ton et al., 2010; Mielke et al., 2011; Faxon et al., 2015), rural continental Europe (Phillips et al., 2012) and northern China (Tham et al., 2016).

Most I-CIMS systems in operation for atmospheric measurement use a radioactive ion source (usually ${ }^{210}$ polonium, an $\alpha$-emitter) to generate the primary iodide ions from methyl iodide $\left(\mathrm{CH}_{3} \mathrm{I}\right)$. Although this type of ion source is well-established and known for its high stability and low chemical background, important and sometimes unsurmountable obstacles to its use are the safety regulations for the shipment, storage and operation of radioactive devices containing polonium. Potential alternatives are corona discharge and X-ray ion sources, as commonly used in atmospheric pressure chemical ionization mass spectrometers (AP-CIMS) (Jost et al., 2003; Skalny et al., 2007; Kürten et al., 2011; Zheng et al., 2015), though the former have not been used for iodide ion generation.

We have developed a CI-QMS instrument (chemical ionization quadrupole mass spectrometer) with an electrical discharge ion source that generates iodide ions without the use of a radioactive ionizer. Although this instrument was originally intended for measurement of PAN, PAA and $\mathrm{ClNO}_{2}$, we discovered that a wider variety of gas-phase species, including $\mathrm{SO}_{2}, \mathrm{HCl}$ and acetic acid could be detected. In the following we show that the instrument is suitable for measurement (at the tens of pptv level) of trace gases connected with sulfur and chlorine chemistry, for example, in the anthropogenically influenced marine boundary layer. Its deployment as a PAN detector is limited to environments where PAN mixing ratios regularly exceed 100 pptv or when high temporal resolution is not necessary.

\section{Instrumentation}

Our chemical ionization quadrupole mass spectrometer (CIQMS) is based on the thermal dissociation technique described by Slusher et al. (2004) and Zheng et al. (2011) and was originally constructed in collaboration with Georgia Tech as a prototype THS Instruments product. A schematic diagram of the instrument in its present form is given in Fig. 1. The major modification, forced by issues of the restricted use of polonium on some platforms, is the replacement of the ${ }^{210} \mathrm{Po}$ ionizer with an electrical discharge ion source (see Fig. 2). The instrument as sketched in Fig. 1 consists of a thermal dissociation region (TDR), discharge ion source (DIS), ion molecule reactor (IMR), collisional dissociation chamber (CDC), octopole ion guide (OCT), quadrupole mass filter (QMF) and detector (DET). The four different vacuum chambers are separated by critical orifices and pumped by a combination of scroll pumps and turbomolecular pumps. The CI-QMS is built into an aircraft rack (HALO, Gulfstream G550) to facilitate airborne operation. A description of the various parts of the instrument as identified in Fig. 1 is given in the following. 


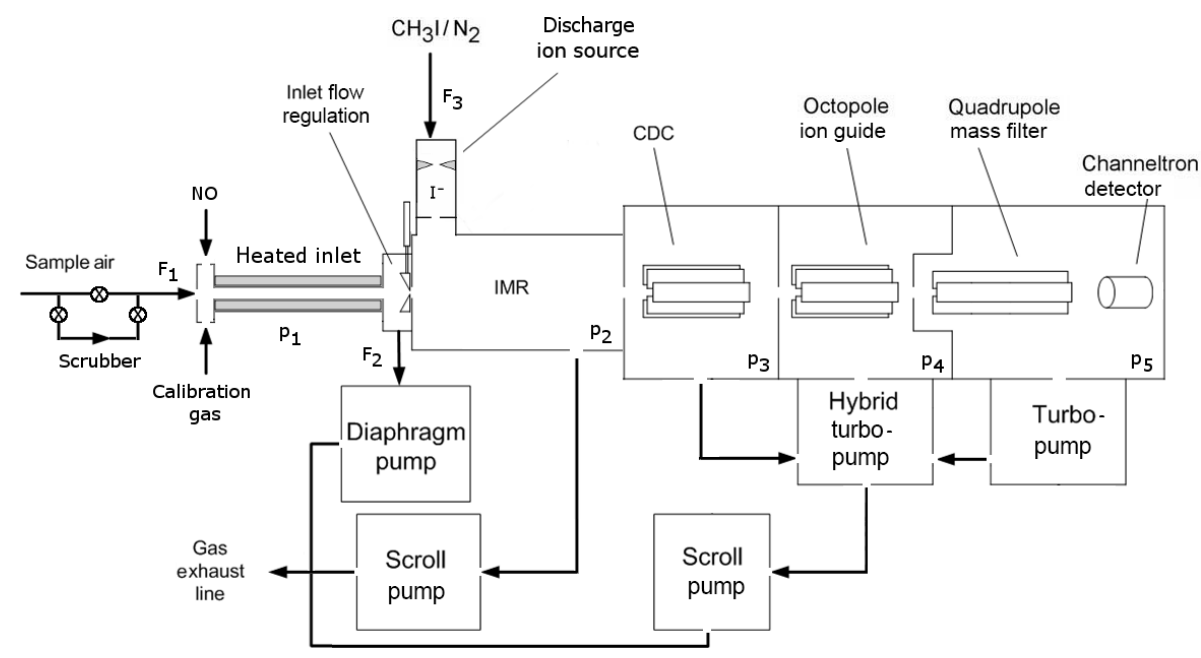

Figure 1. Schematic diagram of the CI-QMS. The air is sampled through the TDR (heated inlet) and enters the IMR after optional bypassing through the scrubber and mixing with calibration gas or nitrogen oxide (NO) for PAN background measurement. Ions are guided to the detector via the CDC, OCT and QMF. Typical flows $(F)$ and pressures $(p)$ are $F_{1}=2.2, F_{2}=1.0, F_{3}=0.8$ slm, $p_{1}=$ ambient pressure, $p_{2}=24, p_{3}=0.6, p_{4}=6 \times 10^{-3}$, and $p_{5}=9 \times 10^{-5} \mathrm{mbar}$.

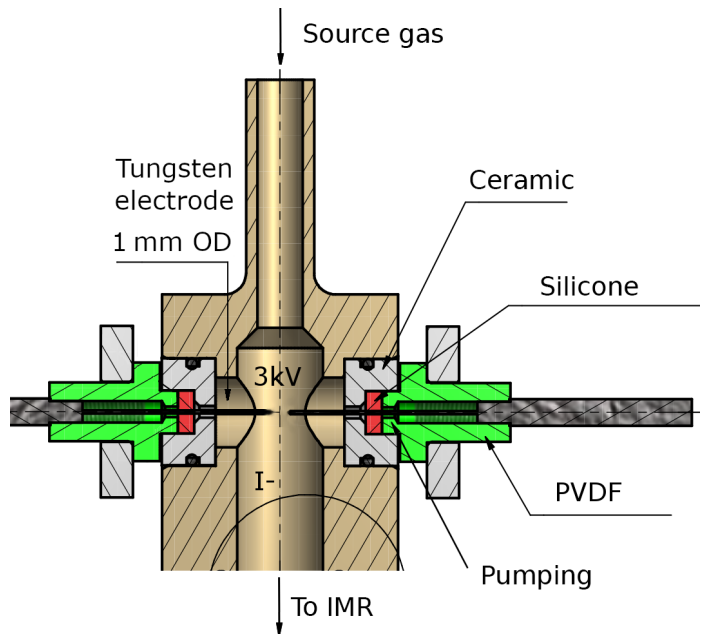

Figure 2. Schematic drawing of the RF discharge ion source. The high voltage and the distance between the tips of the tungsten electrodes are variable, as described in the text. A transformer, which is supplied with up to $200 \mathrm{~V}$ AC from the internal V25 unit, applies temporarily fluctuating potentials to both electrodes. The body of the ion source (coloured in light brown) is made of stainless steel. PVDF is polyvinylidene fluoride. The region around the electrodes can optionally be pumped as described in the text.

\subsection{Thermal dissociation region (TDR)}

During standard operation, a flow $\left(F_{1}\right)$ of $2.2 \mathrm{~L}$ (standard pressure and diameter, STD) $\mathrm{min}^{-1}(\mathrm{slm})$ is sampled through the instrument inlet (see Fig. 1). Ambient air entering the TDR first passes through a $2 \mu \mathrm{m}$ pore size membrane filter (Pall Teflon) to efficiently remove particles. The thermal decomposition of PAN takes place in a $20 \mathrm{~cm}$ length of perfluoroalkoxy (PFA) tubing $(9.3 \mathrm{~mm}$ internal diameter, ID) enclosed in a snugly fitting stainless steel shell heated to $200^{\circ} \mathrm{C}$. A gas temperature of $160-170{ }^{\circ} \mathrm{C}$ was measured inside the heated section of tubing. The last $4 \mathrm{~cm}$ long section of PFA in front of the orifice to the IMR is not actively heated but the gas temperature still remains at $\approx 130^{\circ} \mathrm{C}$, suppressing PAN recombination. Due to space restrictions inside the aircraft rack, the oven is curved over a $90^{\circ}$ bend; however, no significant reduction in sensitivity due to a loss of $\mathrm{CH}_{3} \mathrm{C}(\mathrm{O}) \mathrm{O}_{2}$ on the PFA walls could be observed when compared to a straight TD inlet. A bypass flow of $1 \mathrm{slm}\left(F_{2}\right)$ decreases the inlet residence time and therefore optimizes the peroxyacyl radical transmission. However, as PAN is calibrated in situ with a photochemical source (see Sect. 2.7), the fractional transmission of $\mathrm{CH}_{3} \mathrm{C}(\mathrm{O}) \mathrm{O}_{2}$ does not need to be known. A total of $1.2 \mathrm{slm}\left(F_{1}\right.$ minus $\left.F_{2}\right)$ of the inlet flow enters the IMR via a constant-pressure orifice (see Sect. 2.3) and mixes with the $0.8 \mathrm{slm}$ flow $\left(F_{3}\right)$ of $\mathrm{CH}_{3} \mathrm{I} / \mathrm{N}_{2}$ passing through the ion source. For ground-level deployment, the TDR is held at ambient pressure resulting in a residence time of $\approx 200 \mathrm{~ms}$ at 1 bar. For application in an aircraft, the arrangement of the TDR and constant-pressure orifice can be switched so that a constant pressure of $p_{1}=100 \mathrm{hPa}$ is established in the TDR, resulting in a $40 \mathrm{~ms}$ residence time. With this mode of operation, measurements can be made at altitudes up to $\approx 15 \mathrm{~km}$ depending on aircraft inlet configuration.

\subsection{Discharge ion source (DIS)}

The radio-frequency (RF) discharge ion source represents the major difference to I-CIMS instruments commonly described in the literature. It consists of two tungsten needles, 
their tips placed at a distance of approximately $6 \mathrm{~mm}(\mathrm{ad}-$ justable) from each other (see Fig. 2); changing this distance by a few millimetres did not have a large effect on the overall ion count rate. The vacuum fittings through which the needles enter the discharge volume can optionally be evacuated to eliminate an air leak into the ion source. A $2.5 \mathrm{kV}$ voltage $(20 \mathrm{kHz})$ applied across the tungsten needles leads to the formation of a stable glow discharge ( $3 \mathrm{~mA})$. An RF discharge was chosen for its advantages for operation in negative ion mode and because it is easier to handle with regard to electric field geometry and polarity. The discharge between the tungsten needles can be observed by eye or spectroscopically through a quartz viewing port; a photograph of the glow and the dispersed $\mathrm{N}_{2}$ emission spectrum due to the $\mathrm{B}^{3} \Pi_{g} \leftarrow$ $\mathrm{C}^{3} \Pi_{u}$ transition (Lofthus and Krupenie, 1977; Bayram and Freamat, 2012) is shown in Fig. S1 of the Supplement. The line intensities increase with the voltage applied $(\approx$ factor of 2.5 from 1500 to $3000 \mathrm{~V}$ ), but the relative intensities do not change significantly. From the relative line intensities we calculate that the $\mathrm{N}_{2}$ molecules have a vibrational temperature of $\approx 3000 \mathrm{~K}$ (Svarnas, 2013).

In normal operation, a flow of $0.8 \mathrm{slm}\left(F_{3}\right)$ of $2 \mathrm{ppmv}$ methyl iodide $\left(\mathrm{CH}_{3} \mathrm{I}\right)$ in nitrogen passes through the ionization region. In order to prevent the backflow of air from the IMR into the discharge region, the flow through the ionization region is kept high $(0.8 \mathrm{slm})$ and passes through a $0.9 \mathrm{~mm}$ aperture before entering the IMR.

Similar to the $\alpha$ radiation of a ${ }^{210} \mathrm{Po}$ ionizer, $\mathrm{I}^{-}$ions are formed via dissociative electron attachment to $\mathrm{CH}_{3} \mathrm{I}$. In contrast to typical corona discharge ion sources with a current of a few $\mu \mathrm{A}$ (see, e.g. Kürten et al., 2011), our glow discharge operates at $\approx 3 \mathrm{~mA}$, which leads to highly energetic electrons and ions in the ionization region and a more complex mass spectrum (see Sect. 3).

\subsection{Ion molecule reactor (IMR)}

Under standard operating conditions for ground-level measurements, a flow of $1.2 \mathrm{slm}$ of the air to be analysed $\left(F_{1} \mathrm{mi}-\right.$ nus $\left.F_{2}\right)$ is mixed with the $0.8 \mathrm{slm}$ flow of $\mathrm{CH}_{3} \mathrm{I} / \mathrm{N}_{2}\left(F_{3}\right)$ entering the IMR from the ion source. The IMR is evacuated by a dry scroll vacuum pump (ULVAC DISL-101, $100 \mathrm{~L} \mathrm{~min}^{-1}$ ) and is held at a constant pressure of $24 \mathrm{mbar}\left(p_{2}\right)$. For operation above the boundary layer, an extra $50 \mathrm{~cm}^{3}$ (standard temperature and pressure, STP) $\mathrm{min}^{-1}(\mathrm{sccm})$ flow of humidified air is added just in front of the IMR to ensure that sufficient water vapour is present to form $\mathrm{I}^{-}\left(\mathrm{H}_{2} \mathrm{O}\right)$ clusters. The role of $\mathrm{I}^{-}\left(\mathrm{H}_{2} \mathrm{O}\right)$ and other primary-ion clusters with water is discussed in Sect. 5.

The constant pressure within the IMR is achieved by use of a variable orifice consisting of two metal plates, one with a hole shaped like the 2-D projection of a bike saddle and one with a circular hole, the relative position of which (i.e. the degree of overlap of the holes) is controlled by a stepper motor. The saddle form was chosen as it results in a roughly linear relationship between stepper motor position and mass flow through the orifice, enabling rapid and precise adaptation to changes in ambient pressure even during steep ascents or dives of an aircraft.

The temperature in the IMR is above ambient owing to the inflow of heated gas through the TDR. The exact residence time for trace gases to react with primary ions in the IMR is not accurately known, as the mixing of the gas flows and temperature evolution in the IMR are not well characterized. Based on the mass flow rate into the IMR and its volume $\left(\approx 100 \mathrm{~cm}^{3}\right)$ and disregarding ion drift due to the potential applied between the IMR and the CDC, we calculate an approximate reaction time of $\approx 70 \mathrm{~ms}$.

\subsection{Collisional dissociation chamber (CDC) and octopole ion guide (OCT)}

The CDC region consists of an octopole ion guide to accelerate and collimate the effusive ion beam entering from the IMR. It is separated from the IMR by a critical orifice $\left(0.8 \mathrm{~mm}\right.$ diameter) and held at a pressure of $0.6 \mathrm{mbar}\left(p_{3}\right)$ by the Holweck stage of a turbo-molecular pump (Leybold Turbovac $90 \mathrm{i}, 90 \mathrm{~L} \mathrm{~s}^{-1}$ with an Agilent IDP-3 scroll pump, $50 \mathrm{~L} \mathrm{~min}^{-1}$ as a backup pump). A potential difference of typically $20 \mathrm{~V}$ is applied in the CDC, which results in the declustering of weakly bound adducts (often with $\mathrm{H}_{2} \mathrm{O}$ ), a simplified mass spectrum and a higher sensitivity to the product ion of interest. The de-clustering voltage can be varied independently for each ion of interest, thus optimizing sensitivity for individual trace gases. An example of the variable declustering potential during operation of the CI-QMS in the selected ion monitoring mode (e.g. to measure the $\mathrm{I}^{-}\left(\mathrm{H}_{2} \mathrm{O}\right)$ cluster or differentiate between acetic and peracetic acid) is given below.

An additional octopole ion guide in the subsequent vacuum chamber $\left(6.0 \times 10^{-3}\right.$ mbar, $\left.p_{4}\right)$ further collimates the ion beam and guides it to the detector region. This octopole ion guide is evacuated by the turbo-molecular stage of the Leybold Turbovac $90 \mathrm{i}$.

\subsection{Quadrupole mass filter (QMF) and detector (DET)}

A radio-frequency generator (Balzers QMH 410-3, $1.44 \mathrm{MHz})$ provides a combination of direct and alternating voltage to the quadrupole rods $(10 \mathrm{~mm})$ so that ions with a specific $m / z$ are forced on stable trajectories and reach the detector. These ions are then detected with a channel electron multiplier (ITT Ceramax $7550 \mathrm{M}$ ). The detector chamber is pumped to a pressure of $9.0 \times 10^{-5} \mathrm{mbar}$ $\left(p_{5}\right)$ by a turbo-molecular pump (Varian V70LP, $70 \mathrm{~L} \mathrm{~s}^{-1}$ ).

\subsection{Scrubber}

To determine the instrumental and chemical background, the sampled air is automatically and periodically bypassed into a scrubber (see Fig. 1) consisting of a $20 \mathrm{~cm}$ long stainless 
steel oven filled with steel wool and heated to $120^{\circ} \mathrm{C}$. The trace gases discussed in this work are all destroyed efficiently by the hot metal surfaces whilst leaving the relative humidity unaffected.

\subsection{Photochemical PAN source}

For in situ PAN calibration we use a photochemical source based on the method of Warneck and Zerbach (1992) but with a phosphor-coated Pen-Ray mercury lamp (Jelight, broad emission centred at $285 \mathrm{~nm}$ ) as described by Flocke et al. (2005). Typically, $50 \mathrm{sccm}$ of acetone (200 ppmv in synthetic air, Air Liquide) and $5 \mathrm{sccm}$ of $\mathrm{NO}\left(1 \mathrm{ppmv}\right.$ in $\mathrm{N}_{2}$, Air Liquide) are mixed in a quartz glass reactor $(150 \mathrm{~mL}$ volume, actively cooled by a fan) at 1050 mbar forming PAN (Reactions R1-R4). The calibration source converts NO almost stoichiometrically to PAN (conversion $>95 \%$ ) and results in a mixing ratio of about $4 \mathrm{ppbv}$ of PAN in the TDR. The PAN source is continuously operated and its $55 \mathrm{sccm}$ output drains into the exhaust line, periodically switching into the main flow during scrubbing. The conversion efficiency of NO to PAN was checked using thermal dissociation cavity ring-down spectroscopy as described previously (Phillips et al., 2013). The PAN source also generates both PAA and acetic acid (Reactions R5-R6), which, as described below, are also detected by the CI-QMS.

$$
\begin{aligned}
& \mathrm{CH}_{3} \mathrm{C}(\mathrm{O}) \mathrm{CH}_{3}+h \nu\left(\mathrm{O}_{2}\right) \rightarrow \mathrm{CH}_{3} \mathrm{O}_{2}+\mathrm{CH}_{3} \mathrm{C}(\mathrm{O}) \mathrm{O}_{2} \\
& \mathrm{CH}_{3} \mathrm{O}_{2}+\mathrm{NO}\left(\mathrm{O}_{2}\right) \rightarrow \mathrm{HCHO}+\mathrm{HO}_{2}+\mathrm{NO}_{2} \\
& \mathrm{CH}_{3} \mathrm{C}(\mathrm{O}) \mathrm{O}_{2}+\mathrm{NO}\left(\mathrm{O}_{2}\right) \rightarrow \mathrm{CH}_{3} \mathrm{O}_{2}+\mathrm{CO}_{2}+\mathrm{NO}_{2} \\
& \mathrm{CH}_{3} \mathrm{C}(\mathrm{O}) \mathrm{O}_{2}+\mathrm{NO}_{2}+\mathrm{M} \rightarrow \mathrm{CH}_{3} \mathrm{C}(\mathrm{O}) \mathrm{O}_{2} \mathrm{NO}_{2}+\mathrm{M} \\
& \mathrm{CH}_{3} \mathrm{C}(\mathrm{O}) \mathrm{O}_{2}+\mathrm{HO}_{2} \rightarrow \mathrm{CH}_{3} \mathrm{C}(\mathrm{O}) \mathrm{OOH}+\mathrm{O}_{2} \\
& \quad \rightarrow \mathrm{CH}_{3} \mathrm{C}(\mathrm{O}) \mathrm{OH}+\mathrm{O}_{3}
\end{aligned}
$$

\subsection{Electronics and data acquisition}

The vast majority of the instrument's electronics are controlled by a "V25" system developed in-house. The V25 handles the interplay between single components such as flow controllers, pressure gauges, magnetic valves, thermocouples, heaters, MS potentials and RF generators. All command sequences and measurement cycles (background, calibration, etc.) can be customized and fully automated for operation in aircraft or in remote locations. During measurement campaigns we usually focus on specific trace gases and operate in selected ion monitoring mode, typically monitoring between 3 and 10 different values of $\mathrm{m} / z$. Different $\mathrm{m} / \mathrm{z}$ values can be adjusted in a few milliseconds by variation in the direct voltage and the amplitude of the alternating voltage applied to the quadrupole rods. The integration time of the detector for a single channel is usually set to $10 \mathrm{~ms}$ for primary ions and $100 \mathrm{~ms}$ for product ions, which represents a compromise between high signal-to-noise ratio $(S / N)$ and high temporal resolution. For each $m / z$ monitored, the integrated signal is calculated by summing up eight individual channels, resulting in a total integration time (for one product ion) of about $800 \mathrm{~ms}$. Higher-frequency measurements are possible at the cost of a reduction in the signal-to-noise ratio. The counts for each channel and the integrated counts as well as the most important system parameters are saved on an internal PC card and can additionally be collected and monitored online using customized LabView software. To identify additional traces gases of interest, the whole mass spectrum $(m / z 1-256)$ is occasionally scanned and recorded, which takes about $1-2 \mathrm{~min}$.

\subsection{Size, weight and power consumption}

The CI-QMS is situated in a compact aircraft rack $(65 \mathrm{~cm} \times 55 \mathrm{~cm} \times 140 \mathrm{~cm}$, HALO, Gulfstream G550) with a total weight of $135 \mathrm{~kg}$ and a power consumption of $0.9 \mathrm{~kW}$ with the vacuum pumps as the main power consumers. The two vacuum scroll pumps require $230 \mathrm{~V}$ AC input whereas all the other components are operated with $24 \mathrm{~V}$ DC from an AC/DC converter that either can be supplied with $230 \mathrm{~V}$ AC or $115 \mathrm{~V} \mathrm{AC} \mathrm{(three} \mathrm{phases,} 400 \mathrm{~Hz}$, for aircraft operation).

\section{Primary-ion spectra}

The deployment of an RF discharge source for iodide ion production leads to a more complex primary-ion mass spectrum when compared to use of ${ }^{210} \mathrm{Po}$; consequently, a wider variety of trace gases can be detected. Here we compare both ion sources with respect to sensitivity and achievable detection limits of a number of trace gases. Figure 3 illustrates the primary-ion spectrum with a discharge ion source under various conditions and compares it to that obtained using ${ }^{210} \mathrm{Po}$. The absolute ion count rates for both ion sources are comparable, i.e. up to $(6 \pm 2) \times 10^{6} \mathrm{~Hz}$ for $\mathrm{I}^{-}$. Details of the configurations $(\mathrm{i}-\mathrm{v})$ and primary ions observed are summarized in Table 1.

The primary-ion mass spectrum obtained by passing $\mathrm{CH}_{3} \mathrm{I} / \mathrm{N}_{2}$ through the ${ }^{210}$ Po ionizer (370 MBq, configuration i) at typical relative humidity $\left(50 \%\right.$ at $\left.25^{\circ} \mathrm{C}\right)$ and low declustering voltage $(0-2 \mathrm{~V})$ in the $\mathrm{CDC}$ is dominated by $\mathrm{I}^{-}$ and $\mathrm{I}^{-}\left(\mathrm{H}_{2} \mathrm{O}\right)$ at $m / z 127$ and 145 , with no other significant ion peaks present at $>0.1 \%$ relative signal strength to $\mathrm{I}^{-}$. The background signal for all trace gases of interest, i.e. PAN and PAA at $m / z 59$ and $\mathrm{ClNO}_{2}$ at $m / z 208$ and 210, is consequently negligible and the detection limits are correspondingly low (a few pptv in $1 \mathrm{~s}$ integration time).

With RF discharge and $\mathrm{CH}_{3} \mathrm{I} / \mathrm{N}_{2}$ as an ion source gas (configuration iii, applied in all the field measurements we discuss below), the primary-ion mass spectrum is more complex with additional ions such as $\mathrm{CNO}^{-}(\mathrm{m} / \mathrm{z} 42,37 \%$ of $\mathrm{I}^{-}$at low de-clustering), $\mathrm{CO}_{3}^{-}\left(\mathrm{m} / z \mathrm{z} 60,32 \%\right.$ of $\left.\mathrm{I}^{-}\right), \mathrm{NO}_{3}^{-}$ $\left(\mathrm{m} / z 62,5 \%\right.$ of $\left.\mathrm{I}^{-}\right), \mathrm{IO}_{3}^{-}\left(m / z 175,28 \%\right.$ of $\left.\mathrm{I}^{-}\right)$and $\mathrm{I}(\mathrm{CN})_{2}^{-}$ $\left(m / z 179,67 \%\right.$ of $\left.\mathrm{I}^{-}\right)$. With the de-clustering voltage set to 
Table 1. Ion source configurations according to Fig. 3 and primary ions observed.

\begin{tabular}{lllll}
\hline Configuration & Ion source & Source gas & Inlet gas & Primary ions (most abundant first) \\
\hline i & ${ }^{210} \mathrm{Po}$ & $\mathrm{CH}_{3} \mathrm{I}+\mathrm{N}_{2}$ & Syn. air & $\mathrm{I}^{-}, \mathrm{I}^{-}\left(\mathrm{H}_{2} \mathrm{O}\right)$ \\
ii & ${ }^{210} \mathrm{Po}$ & $\mathrm{CH}_{3} \mathrm{I}+\mathrm{Air}$ & Syn. air & $\mathrm{I}^{-}, \mathrm{I}^{-}\left(\mathrm{H}_{2} \mathrm{O}\right), \mathrm{O}_{2}^{-}, \mathrm{O}_{2}^{-}\left(\mathrm{H}_{2} \mathrm{O}\right), \mathrm{CO}_{3}^{-}$ \\
iii & $R F$ discharge & $\mathrm{CH}_{3} \mathrm{I}+\mathrm{N}_{2}$ & Syn. air & $\mathrm{I}^{-}, \mathrm{I}^{-}\left(\mathrm{H}_{2} \mathrm{O}\right), \mathrm{I}(\mathrm{CN}) \frac{2}{2}, \mathrm{CNO}^{-}, \mathrm{NO}_{3}^{-}, \mathrm{IO}_{3}^{-}$ \\
iv & RF discharge & $\mathrm{CH}_{3} \mathrm{I}+\mathrm{N}_{2}$ & $\mathrm{~N}_{2}$ & $\mathrm{I}^{-}, \mathrm{I}^{-}\left(\mathrm{H}_{2} \mathrm{O}\right), \mathrm{I}(\mathrm{CN})-\mathrm{IH}_{2}\left(\mathrm{CN}^{-}\right.$ \\
v & $\mathrm{RF}$ discharge & $\mathrm{I}_{2}+\mathrm{N}_{2}$ & Syn. air & $\mathrm{I}^{-}, \mathrm{I}^{-}\left(\mathrm{H}_{2} \mathrm{O}\right), \mathrm{IO}_{3}^{-}, \mathrm{IO}_{4}^{-}, \mathrm{IO}_{2}^{-}, \mathrm{NO}_{3}^{-}$ \\
\hline
\end{tabular}

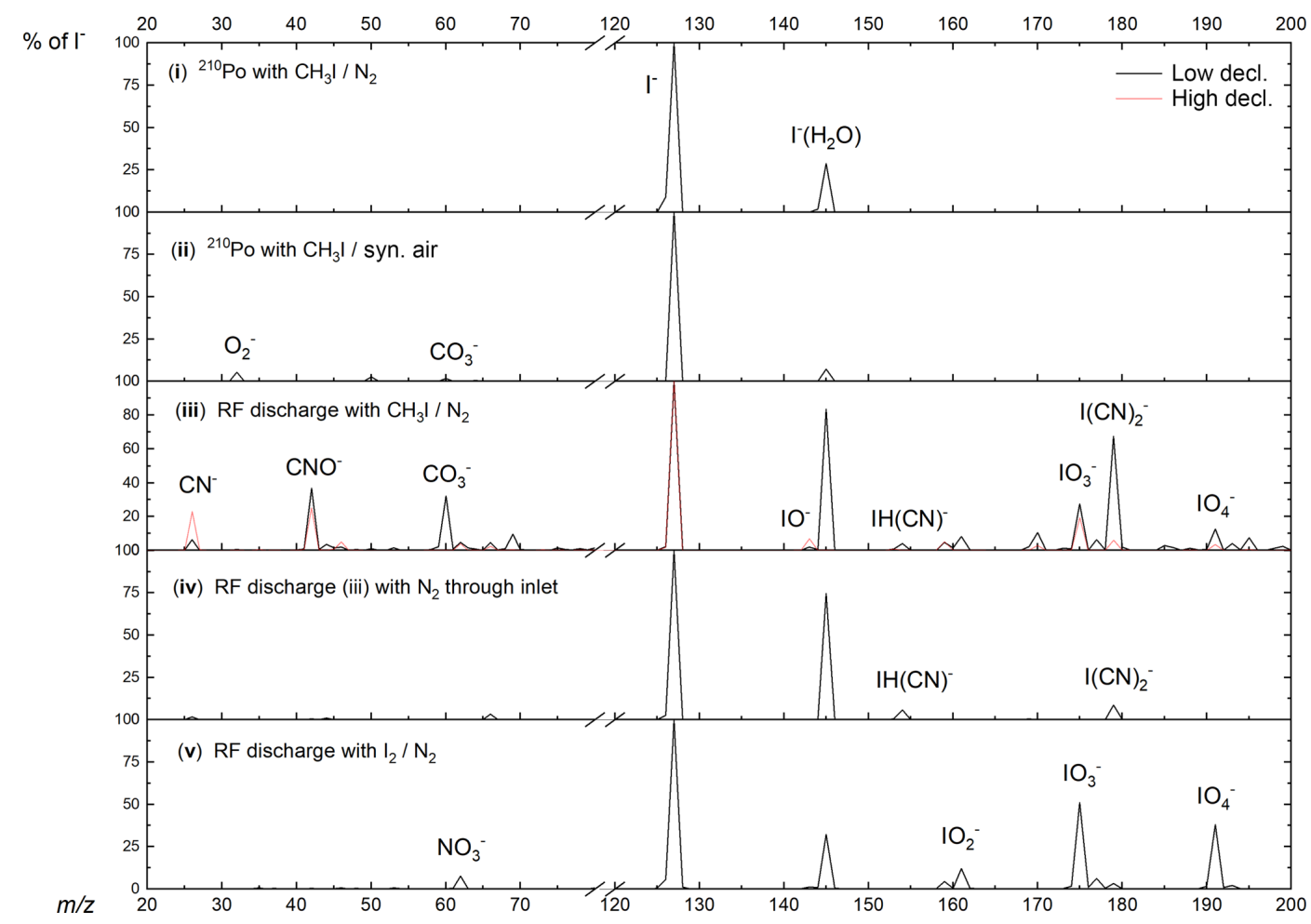

Figure 3. Primary-ion spectra (using $\mathrm{I}_{2} / \mathrm{N}_{2}$ (v) or $\mathrm{CH}_{3} \mathrm{I} / \mathrm{N}_{2}$ (iii-iv) and using either pure synthetic air (iii) or $\mathrm{N}_{2}$ (iv) for the inlet gas) obtained using the RF discharge (iii-v) or ${ }^{210} \mathrm{Po}$ (i-ii) as an ion source. The integrated counts (eight channels) for each $m / z$ normalized to the highest peak present are shown, which is $\mathrm{I}^{-}$. For this reason, true peak shapes are not visible. A description of the different configurations can be found in Table 1 .

$20 \mathrm{~V}$ (the best $S / N$ ratio for most molecules of interest), the background count rate compared with ${ }^{210} \mathrm{Po}$ is elevated by at least 1 order of magnitude for $m / z 59$, which is used to monitor PAN and PAA. The high chemical background is assumed to originate from $\mathrm{CH}_{3} \mathrm{I}$ breakdown in the discharge ion source and formation of $\mathrm{O}_{2}^{-}$in the ion source and IMR. When pumping the region around the ion source needles, the formation of $\mathrm{NO}_{3}^{-}(\mathrm{m} / \mathrm{z} 62)$ can be reduced by a factor of 2 but the other ions still show similar ion count rates. This observation suggests that a small amount of $\mathrm{O}_{2}$ entering the ion source can form additional $\mathrm{NO}_{3}^{-}$. According to manufacturer's specifications the nitrogen supply $\left(\mathrm{N}_{2} 6.0\right.$, Westfalen AG) can contain up to 0.5 ppmv $\mathrm{O}_{2}$ and $\mathrm{H}_{2} \mathrm{O}$, which can also result in the formation of $\mathrm{NO}_{3}^{-}$in the ion source.
To examine the influence of oxygen in the IMR on the primary ions formed, we switched the main gas flow (i.e. that which does not pass through the RF discharge) from ambient air to pure nitrogen (configuration iv). In this case, apart from $\mathrm{I}^{-}$, only $\mathrm{CN}^{-}\left(\mathrm{m} / \mathrm{z} 26,2 \%\right.$ of $\mathrm{I}^{-}$at low de-clustering $)$, $\mathrm{IH}(\mathrm{CN})^{-}\left(m / z 154,6 \%\right.$ of $\left.\mathrm{I}^{-}\right)$and $\mathrm{I}(\mathrm{CN})_{2}^{-}(m / z 179,9 \%$ of $\left.\mathrm{I}^{-}\right)$remained. While these conditions are unrealistic for atmospheric measurements they clearly indicate that the presence of additional primary ions containing $\mathrm{O}$ atoms and the elevated chemical background on $m / z$ of interest are highly dependent on the amount of $\mathrm{O}_{2}$ present in the IMR. With pure $\mathrm{N}_{2}$ in the inlet (configuration iv), background signals at $m / z 59,188,207$ and 208 could be lowered by about an order of magnitude. The use of $\mathrm{N}_{2}$ results in a drastically reduced sensitivity to $\mathrm{SO}_{2}$, as the primary ion used to detect 


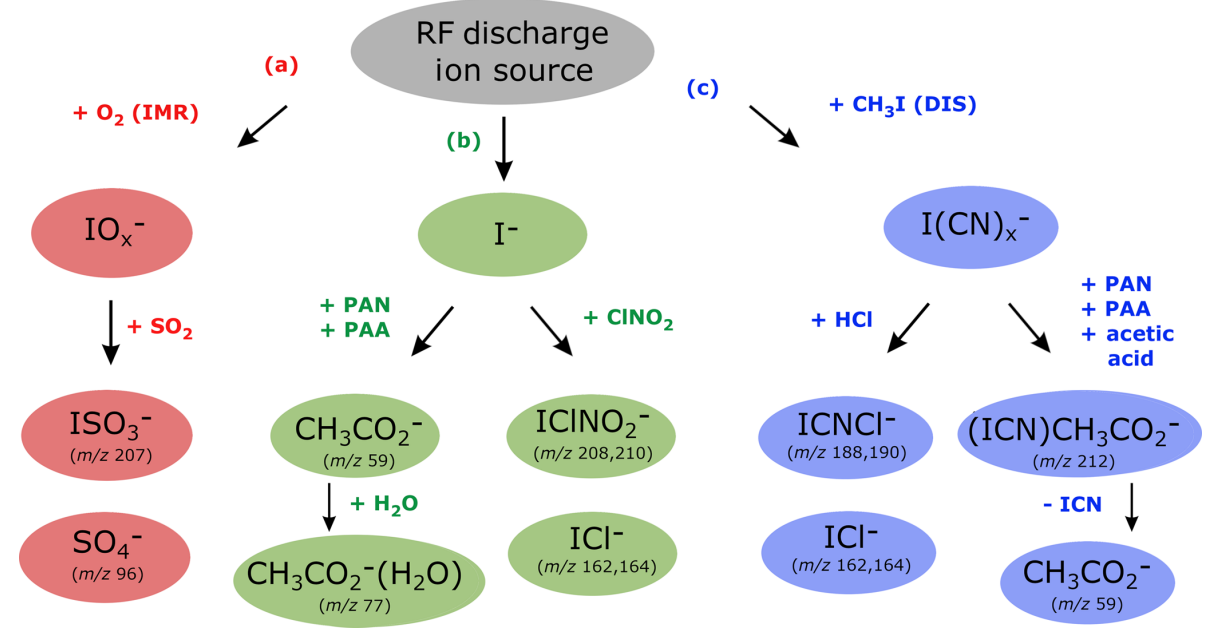

Figure 4. Ion detection schemes for $\mathrm{SO}_{2}$, PAN, PAA, acetic acid, $\mathrm{ClNO}_{2}$ and $\mathrm{HCl}$ using the $\mathrm{RF}$ discharge ion source.

it $\left(\mathrm{IO}_{3}^{-}\right.$; see Sect. 4.2) is no longer abundant. This is illustrated in Fig. S2, where we plot the dependence of the $\mathrm{IO}_{3}^{-}$ signal $(\mathrm{m} / z, 175)$ on the fractional pressure of $\mathrm{O}_{2}$ in the inlet and the signal at $m / z 207\left(\mathrm{ISO}_{3}^{-}\right.$) used to monitor $\mathrm{SO}_{2}$ (see Sect. 4.2). Clearly, detection of $\mathrm{SO}_{2}$ is not possible without the presence of $\mathrm{O}_{2}$ and is not available when using ${ }^{210} \mathrm{Po}$ as an ion source.

In an attempt to improve the detection limit for PAN by lowering the background signal on $m / z 59, \mathrm{I}_{2}$, produced from a flow of nitrogen over iodine crystals (configuration v), was used instead of $\mathrm{CH}_{3} \mathrm{I}$. This resulted in a significant reduction of background signals, especially on $\mathrm{m} / z 59$ and the disappearance of all the ion peaks containing $\mathrm{C}$ and $\mathrm{N}$ atoms with just $\mathrm{IO}_{3}^{-}\left(\mathrm{m} / \mathrm{z} 175,51 \%\right.$ of $\left.\mathrm{I}^{-}\right), \mathrm{IO}_{4}^{-}(\mathrm{m} / \mathrm{z} 191$, $38 \%$ of $\left.\mathrm{I}^{-}\right), \mathrm{IO}_{2}^{-}\left(m / z 159,12 \%\right.$ of $\left.\mathrm{I}^{-}\right)$and $\mathrm{NO}_{3}^{-}(m / z 62$, $8 \%$ of $\mathrm{I}^{-}$) remaining. However, use of $\mathrm{I}_{2}$ was accompanied by a drastic lowering of the sensitivity to PAN, despite comparable $\mathrm{I}^{-}$ion counts at $m / z 127$. The decrease in sensitivity can be traced back to equilibrium between $\mathrm{I}^{-}, \mathrm{I}_{2}$ and $\mathrm{I}_{3}^{-}$.

$\mathrm{I}^{-}+\mathrm{I}_{2}+\mathrm{M} \leftarrow \rightarrow \mathrm{I}_{3}^{-}+\mathrm{M}$

An equilibrium constant $\left(K_{\text {eq }}\right.$, in $\left.\operatorname{bar}^{-1}\right)$ of $K_{\text {eq }}=\left[\mathrm{I}_{3}^{-}\right] /\left[\mathrm{I}^{-}\right]\left[\mathrm{I}_{2}\right]=\exp (11300 / T)$ for Reaction (R7) (based on the Gibbs free energy of $-94.14 \mathrm{~kJ} \mathrm{~mol}^{-1}$; NIST Webbook, 2010) and an estimate (based on its saturation vapour pressure) of the concentration of $\mathrm{I}_{2}$ of $\approx 2 \times 10^{-7} \mathrm{bar}$ results in the complete dominance (by several orders of magnitude) of $\left[\mathrm{I}_{3}^{-}\right]$compared to $\left[\mathrm{I}^{-}\right]$in the IMR. While the presence of large concentrations of $\mathrm{I}_{3}^{-}$may explain the large signal at $m / z 127$ following de-clustering, we conclude that the reaction between $\mathrm{I}_{3}^{-}$and $\mathrm{CH}_{3} \mathrm{C}(\mathrm{O}) \mathrm{O}_{2}$ is very inefficient or does not lead to $\mathrm{CH}_{3} \mathrm{CO}_{2}^{-}$formation. $\mathrm{I}_{2}$ does not represent a feasible alternative to $\mathrm{CH}_{3} \mathrm{I}$ for PAN measurement and $\mathrm{HCl}$ detection is not possible. However, we can still detect $\mathrm{SO}_{2}$ via $\mathrm{IO}_{x}^{-}$primary ions and also acetic acid, presumably due to $\left(\mathrm{IO}_{x}^{-}\right)$clusters with $\mathrm{CH}_{3} \mathrm{C}(\mathrm{O}) \mathrm{OH}$.
In another experiment performed with the ${ }^{210}$ Po source, synthetic air instead of nitrogen was flowing over the polonium ionizer (configuration ii), simulating a huge leak of oxygen into the source. Besides $\mathrm{I}^{-}$and $\mathrm{I}^{-}\left(\mathrm{H}_{2} \mathrm{O}\right), \mathrm{O}_{2}^{-}$ $\left(\mathrm{m} / \mathrm{z}, 32,5 \%\right.$ of $\left.\mathrm{I}^{-}\right), \mathrm{O}_{2}^{-}\left(\mathrm{H}_{2} \mathrm{O}\right)\left(\mathrm{m} / \mathrm{z} 50,3 \%\right.$ of $\left.\mathrm{I}^{-}\right)$and $\mathrm{CO}_{3}^{-}\left(\mathrm{m} / z 60,2 \%\right.$ of $\left.\mathrm{I}^{-}\right)$were present, but ions like $\mathrm{IO}_{x}^{-}$ and $\mathrm{I}(\mathrm{CN})_{x}^{-}$that are probably responsible for the detection of $\mathrm{SO}_{2}$ and $\mathrm{HCl}$ (see below) were not observed as they are unique to the RF discharge ion source. In combination with the experiment where the housing around the tungsten needles was evacuated, we conclude that a leak of $\mathrm{O}_{2}$ into the discharge region might increase $\mathrm{O}_{2}^{-}$and $\mathrm{NO}_{3}^{-}$but is not responsible for the complex primary-ion spectrum observed with our discharge ion source. No change in the ion spectrum was observed when the linear steel tubing between the ion source and IMR was replaced by tubing with a $90^{\circ}$ bend. This result precludes an important role for ion formation via highly energetic radiation from the ionization region reaching the IMR interacting with $\mathrm{O}_{2}$. The diffusion of oxygen from the IMR into the ion source is also very unlikely due to a high-volume flow between the ion source and IMR and the use of a small aperture. We conclude that the role of $\mathrm{O}_{2}$ in the formation of primary ions containing $\mathrm{I}, \mathrm{O}, \mathrm{C}$ and $\mathrm{N}$ atoms in the IMR is most likely related to its role as a trapper and carrier of electrons, possibly as excited $\mathrm{O}_{2}^{-}$anions.

\section{Detection schemes and calibration methods}

Figure 4 shows which trace gases we can detect with our instrument using the RF discharge ion source. The middle branch (b) represents ionization via $\mathrm{I}^{-}$and its water cluster ion and is the same as ${ }^{210}$ Po-based ion generation schemes frequently used for detection of PAN (Slusher et al., 2004), PAA (Phillips et al., 2013) and $\mathrm{ClNO}_{2}$ (McNeill et al., 2006). The outer branches ( $\mathrm{a}$ and $\mathrm{c}$ ) are unique to our CI-QMS using 
the discharge ion source and can be attributed to the presence of different primary ions. The presence of $\mathrm{H}, \mathrm{C}$ and $\mathrm{N}$ atoms from $\mathrm{CH}_{3} \mathrm{I} / \mathrm{N}_{2}$ breakdown in the discharge region leads to the existence of the right-hand branch (c) that disappears when $\mathrm{CH}_{3} \mathrm{I}$ is replaced by $\mathrm{I}_{2}$ (see Sect. 3, configuration v). The usual presence of oxygen inside the IMR is responsible for the existence of the left-hand branch (a) and is not available with configuration (iv) in which nitrogen was used for the main gas flow instead of synthetic air. For the combined detection of $\mathrm{PAN}, \mathrm{ClNO}_{2}, \mathrm{SO}_{2}, \mathrm{HCl}$, peracetic and acetic acid, configuration (iii) was used in all of our field measurements. In the following we discuss in detail the ion-molecule reactions involved in the detection of these trace gases and also outline how the CI-QMS is calibrated and which sensitivities and detection limits can be achieved.

\subsection{PAN, PAA and acetic acid}

PAN, PAA and acetic acid are all detected as $\mathrm{CH}_{3} \mathrm{CO}_{2}^{-}$at $m / z$ 59. Depending on the relative humidity and the declustering potential in the $\mathrm{CDC}$, clusters of $\mathrm{CH}_{3} \mathrm{CO}_{2}^{-}$with $\mathrm{H}_{2} \mathrm{O}$ are observed at $m / z 77$. Sensitivities and product yields for the detection of these three molecules are summarized in Table 2. The detection mechanism for PAN using $\mathrm{I}^{-}$primary ions is the same as that reported when using ${ }^{210} \mathrm{Po}$ as an ion source (Slusher et al., 2004). PAN is thermally decomposed inside the TDR into a peroxy radical $\left(\mathrm{CH}_{3} \mathrm{C}(\mathrm{O}) \mathrm{O}_{2}\right)$ and $\mathrm{NO}_{2}$ via Reaction ( $\mathrm{R} 8$ ). The rate coefficient for the thermal decomposition of PAN (at $453 \mathrm{~K}$ and 1 bar) is $\approx 2000 \mathrm{~s}^{-1}$ (Atkinson et al., 2006; IUPAC, 2018), so that $>99.99 \%$ of PAN should be thermally dissociated within $200 \mathrm{~ms}$. This could be confirmed by measurement of the signal due to a stable PAN source whilst varying the inlet temperature. The $\mathrm{CH}_{3} \mathrm{C}(\mathrm{O}) \mathrm{O}_{2}$ product reacts with $\mathrm{I}^{-}$in the IMR to form $\mathrm{CH}_{3} \mathrm{CO}_{2}^{-}(m / z$ 59) via Reaction (R9) involving clusters with water vapour. The detection of PAA with $\mathrm{I}^{-}$primary ions is believed to be direct via Reaction (R10) (Phillips et al., 2013).

$$
\begin{aligned}
& \mathrm{CH}_{3} \mathrm{C}(\mathrm{O}) \mathrm{O}_{2} \mathrm{NO}_{2}+\mathrm{M} \rightarrow \mathrm{CH}_{3} \mathrm{C}(\mathrm{O}) \mathrm{O}_{2}+\mathrm{NO}_{2}+\mathrm{M} \\
& \mathrm{CH}_{3} \mathrm{C}(\mathrm{O}) \mathrm{O}_{2}+\mathrm{I}^{-}\left(\mathrm{H}_{2} \mathrm{O}\right)_{n} \rightarrow \mathrm{CH}_{3} \mathrm{C}(\mathrm{O}) \mathrm{O}^{-}\left(\mathrm{H}_{2} \mathrm{O}\right)_{n}+\mathrm{IO} \\
& \mathrm{CH}_{3} \mathrm{C}(\mathrm{O}) \mathrm{OOH}+\mathrm{I}^{-}\left(\mathrm{H}_{2} \mathrm{O}\right)_{n} \rightarrow \mathrm{CH}_{3} \mathrm{C}(\mathrm{O}) \mathrm{O}^{-}\left(\mathrm{H}_{2} \mathrm{O}\right)_{n}+\mathrm{HOI}
\end{aligned}
$$

When using the RF discharge ion source there is also an additional pathway for PAN and PAA detection, involving $\mathrm{I}(\mathrm{CN})_{2}^{-}$primary ions, resulting in the formation of $\mathrm{I}(\mathrm{CN}) \mathrm{CH}_{3} \mathrm{CO}_{2}^{-}$, which is observed at $\mathrm{m} / z 212$ when declustering is switched off. With de-clustering this ion fragments to $m / z 59$. However, the sensitivity is relatively low, and the selectivity is not improved as acetic acid is also detected at this $m / z$ (see Table 2).

The separation of PAN from PAA and acetic acid signals when sampling air masses which contain both trace gases can be achieved by cooling the TDR to prevent formation of $\mathrm{CH}_{3} \mathrm{C}(\mathrm{O}) \mathrm{O}_{2}$ and thus detection of PAN (Phillips et al., 2013) or by adding $\mathrm{NO}$ to the TDR in order to remove $\mathrm{CH}_{3} \mathrm{C}(\mathrm{O}) \mathrm{O}_{2}$ (Reaction R11).

$$
\mathrm{CH}_{3} \mathrm{C}(\mathrm{O}) \mathrm{O}_{2}+\mathrm{NO} \rightarrow \mathrm{CH}_{3}+\mathrm{CO}_{2}+\mathrm{NO}_{2}
$$

The latter method has the advantage of being more rapid, as NO can be switched in and out of the TDR in a matter of seconds, whereas cooling of the inlet may take minutes. Generally we add NO (100 ppmv in nitrogen, Air Liquide) to the TDR at a mixing ratio of $0.23 \mathrm{ppmv}(3.7 \times$ $10^{12}$ molecule $\mathrm{cm}^{-3}$ ). Given the approximate residence time of ca. $200 \mathrm{~ms}$ in the TDR (calculated from the volume of the TDR and the volumetric flow rate) and the rate coefficient for Reaction (R11) of $1.4 \times 10^{-11} \mathrm{~cm}^{3}$ molecule ${ }^{-1} \mathrm{~s}^{-1}$ at $453 \mathrm{~K}$ (Atkinson et al., 2004; IUPAC, 2018), we calculate that more than $99.99 \%$ of the $\mathrm{CH}_{3} \mathrm{C}(\mathrm{O}) \mathrm{O}_{2}$ is removed by titration with NO. When NO is added, we therefore measure only PAA (or the sum of PAA and acetic acid, depending on de-clustering potential; see below). The signal due to PAN is then calculated by subtracting the interpolated signal during NO addition.

The use of the RF discharge source also results in sensitivity to acetic acid at $m / z 59$, which is not observed using ${ }^{210} \mathrm{Po}$ as an ion source. Rather, detection of acetic acid has been reported at $m / z 187\left(\mathrm{ICH}_{3} \mathrm{C}(\mathrm{O}) \mathrm{OH}^{-}\right)$(Lee et al., 2014). Our instrument is relatively insensitive for acetic acid at $m / z \quad 187$ and, without de-clustering, we measure acetic acid mainly as $(\mathrm{CNO}) \mathrm{CH}_{3} \mathrm{C}(\mathrm{O}) \mathrm{OH}^{-}(\mathrm{m} / z$ 102) and $\mathrm{I}(\mathrm{CN}) \mathrm{CH}_{3} \mathrm{CO}_{2}^{-}(\mathrm{m} / z$ 212).

When monitoring $\mathrm{m} / \mathrm{z} 59$ using the discharge ion source, the background signal during NO addition consists of both PAA and acetic acid. To differentiate between them we make use of the fact that the relative sensitivity to PAA and acetic acid at $m / z 59$ depends on the de-clustering potential applied in the CDC. We find that acetic acid is only detected at $m / z 59$ when a de-clustering voltage of about $20 \mathrm{~V}$ is applied, whereas PAA is detected at $m / z 59$ both with and without declustering, albeit with different sensitivity. The difference is related to the fact that for PAA the product ion is formed directly in Reaction (R10), whereas acetic acid is believed to initially form a cluster with $\mathrm{I}(\mathrm{CN})_{2}^{-}$(Reaction R12) and only dissociate to $\mathrm{CH}_{3} \mathrm{CO}_{2}^{-}$when the $20 \mathrm{~V}$ de-clustering voltage is applied (Reaction $\mathrm{R} 13) . \mathrm{ICN}^{-}, \mathrm{IH}(\mathrm{CN})^{-}$and $\mathrm{I}(\mathrm{CN})_{2}^{-}$are all potential primary ions for detection of acetic acid, though $\mathrm{I}(\mathrm{CN})_{2}^{-}$is the most abundant. When NO is added, the mixing ratio of acetic acid can be calculated by subtracting the signal without de-clustering from the signal with de-clustering. Unfortunately, the chemical background without de-clustering at $m / z 59$ is a factor of 2.5 higher than with de-clustering and the sensitivity is reduced, which increases the LOD for detection of PAA significantly (see Table 2).

$$
\begin{aligned}
& \mathrm{CH}_{3} \mathrm{C}(\mathrm{O}) \mathrm{OH}+\mathrm{I}(\mathrm{CN})_{2}^{-} \rightarrow \mathrm{HCN}+\mathrm{I}(\mathrm{CN}) \mathrm{CH}_{3} \mathrm{CO}_{2}^{-} \\
& \mathrm{I}(\mathrm{CN}) \mathrm{CH}_{3} \mathrm{CO}_{2}^{-}+\Delta U \rightarrow \mathrm{ICN}+\mathrm{CH}_{3} \mathrm{CO}_{2}^{-}
\end{aligned}
$$

Results of combined PAA and acetic acid measurements from the CYPHEX field campaign and speciation via chang- 
Table 2. Sensitivity and limit of detection of the CI-QMS for PAN, PAA, acetic acid, $\mathrm{CINO}_{2}, \mathrm{SO}_{2}$ and $\mathrm{HCl}$.

\begin{tabular}{|c|c|c|c|c|c|c|c|}
\hline \multirow[b]{2}{*}{ Reactant } & \multirow[b]{2}{*}{ Product } & \multirow[b]{2}{*}{$m / z$} & \multicolumn{3}{|c|}{ RF discharge ion source } & \multicolumn{2}{|c|}{${ }^{210}$ Po ion source } \\
\hline & & & Yield/\% & $S^{a}$ & $\mathrm{LOD}^{\mathrm{b}} / \mathrm{pptv}$ & $S^{a}$ & $\mathrm{LOD}^{\mathrm{b}} / \mathrm{pptv}$ \\
\hline \multirow[t]{2}{*}{ PAN } & $\mathrm{CH}_{3} \mathrm{CO}_{2}^{-}$ & 59 & 98 & 1.04 & $34^{\mathrm{c}}$ & 17 & 3 \\
\hline & $\mathrm{I}(\mathrm{CN}) \mathrm{CH}_{3} \mathrm{CO}_{2}^{-}$ & 212 & 2 & & & & \\
\hline PAA & $\mathrm{CH}_{3} \mathrm{CO}_{2}^{-}$ & 59 & 98 & $0.22^{\mathrm{d}}$ & $194^{\mathrm{d}}$ & 5.7 & 4 \\
\hline \multirow[t]{3}{*}{ Acetic acid } & $\mathrm{CH}_{3} \mathrm{CO}_{2}^{-}$ & 59 & 95 & 0.62 & 57 & & \\
\hline & $\mathrm{CH}_{3} \mathrm{C}(\mathrm{O}) \mathrm{OH}^{-}$ & 60 & 3 & & & & \\
\hline & $\mathrm{I}(\mathrm{CN}) \mathrm{CH}_{3} \mathrm{CO}_{2}^{-}$ & 212 & 2 & & & & \\
\hline \multirow[t]{4}{*}{$\mathrm{ClNO}_{2}$} & $\mathrm{ICINO}_{2}^{-}$ & 208 & 30 & 0.60 & 12 & 3.5 & 3 \\
\hline & $\mathrm{ICINO}_{2}^{-}$ & 210 & 10 & & & & \\
\hline & $\mathrm{ICl}^{-}{ }^{2}$ & 162 & 45 & & & & \\
\hline & $\mathrm{ICl}^{-}$ & 164 & 15 & & & & \\
\hline \multirow[t]{8}{*}{$\mathrm{SO}_{2}$} & $\mathrm{ISO}_{3}^{-}$ & 207 & 8 & 0.09 & 56 & & \\
\hline & $\mathrm{ISO}_{4}^{-}$ & 223 & 2 & & & & \\
\hline & $\mathrm{SO}_{3}^{-}$ & 80 & 10 & & & & \\
\hline & $\mathrm{HSO}_{3}^{-}$ & 81 & 17 & & & & \\
\hline & $\mathrm{SO}_{4}^{-}$ & 96 & 19 & & & & \\
\hline & $\mathrm{HSO}_{4}^{-}$ & 97 & 30 & & & & \\
\hline & $\mathrm{SO}_{5}^{-}$ & 112 & 9 & & & & \\
\hline & $\mathrm{HSO}_{5}^{-}$ & 113 & 5 & & & & \\
\hline \multirow[t]{6}{*}{$\mathrm{HCl}$} & $\mathrm{I}(\mathrm{CN}) \mathrm{Cl}^{-}$ & 188 & 18 & 0.14 & 135 & & \\
\hline & $\mathrm{I}(\mathrm{CN}) \mathrm{Cl}^{-}$ & 190 & 6 & & & & \\
\hline & $\mathrm{ICl}^{-}$ & 162 & 6 & & & & \\
\hline & $\mathrm{ICl}^{-}$ & 164 & 2 & & & & \\
\hline & $\mathrm{Cl}^{-}$ & 35 & 51 & & & & \\
\hline & $\mathrm{Cl}^{-}$ & 37 & 17 & & & & \\
\hline
\end{tabular}

ing the CDC parameters can be found in Derstroff et al. (2017). An exemplary time series showing the different measurement modes of the CI-QMS (scrubber, ambient, NO addition) and the differences in detection of PAA and acetic acid when applying a de-clustering voltage is provided in Fig. S3.

An enhancement in sensitivity to acetic acid at $\mathrm{m} / z 59$ when using the RF discharge ion source compared to ${ }^{210} \mathrm{Po}$ is illustrated by the signals obtained from the photochemical source used to generate PAN, which also generates unquantified amounts of both PAA and acetic acid (Sect. 2.7, Reactions R5 and R6). When using the RF discharge ion source and $20 \mathrm{~V}$ de-clustering voltage, the signal ratio of $\mathrm{PAN} /(\mathrm{PAN}+\mathrm{PAA}+$ acetic acid) at $m / z 59$ is $\approx 0.2$. In contrast, using ${ }^{210} \mathrm{Po}$ as an ion source the ratio is ca. 0.9 . As the relative sensitivity $(\mathrm{m} / \mathrm{z} 59)$ to PAN and PAA is similar, this change in ratio reflects enhanced instrument sensitivity to acetic acid when using the discharge ion source with declustering. This represents a significant disadvantage of the RF discharge source for PAN detection compared to ${ }^{210} \mathrm{Po}$. Not only is the instrumental background at $\mathrm{m} / \mathrm{z} 59$ higher, the presence of acetic acid in ambient air samples means that a larger and more variable chemical background signal has to be subtracted to calculate the PAN mixing ratio, which increases the limit of detection and overall uncertainty significantly.

\section{Calibration of PAN, PAA and acetic acid}

The in situ calibration of PAN is described in Sect. 2.7. The overall uncertainty of the calibration, based on the uncertainty in dilution, the mixing ratio of the NO calibration cylinder (1 ppmv) and the conversion efficiency from NO to $\mathrm{PAN}$ is $\approx 10 \%$.

For PAA, two methods, both using a diffusion source containing a commercially available $39 \%$ solution of PAA in acetic acid, have been used to calibrate the CI-QMS. In the first, we use simultaneous CI-QMS and wet-chemical peroxide-specific detection of PAA based on the horseradish peroxidase/catalase/p-hydroxyphenyl fluorescence measurement technique (Lazrus et al., 1986) in which organic peroxides (and peracids) are converted to $\mathrm{H}_{2} \mathrm{O}_{2}$ (AL2021, Aero- 
Laser $\mathrm{GmbH})$. The wet chemical method is calibrated via standard $\mathrm{H}_{2} \mathrm{O}_{2}$ solutions and the overall uncertainty (related to scrubbing efficiency of PAA) is $13 \%$. As the AL2021 is not always available during the campaign, we developed a second approach in which PAA undergoes transformation to $\mathrm{I}_{3}^{-}$(aq), which can be quantified using aqueous-phase absorption spectroscopy (Awtrey and Connick, 1951; Friedrich, 2015). Based on uncertainty in the scavenging of PAA into an acidified, aqueous solution, uncertainty associated with the absorption cross section of $\mathrm{I}_{3}^{-}$and the reproducibility of $\mathrm{I}_{3}^{-}$ signals when sampling from a constant source of PAA, we estimate the total uncertainty of the $\mathrm{I}_{3}^{-}$method to be $\approx 30 \%$.

For the calibration of acetic acid we use a permeation source ( $7.33 \mathrm{ng} \mathrm{min}-1$ at $30^{\circ} \mathrm{C}$, Metronics) with an uncertainty of $8 \%$. Additionally, we sampled the output of a diffusion source of pure liquid acetic acid simultaneously using the CI-QMS (41.2 ppbv after dilution) and an infrared absorption spectrometer measuring $\mathrm{CO}_{2}$ (LI-COR) following the stoichiometric thermal oxidation of acetic acid to $\mathrm{CO}_{2}$ (Veres et al., 2010). The uncertainty of this calibration method is $\approx 10 \%$. Within combined uncertainty both methods indicated the same sensitivity of the CI-QMS to acetic acid.

\subsection{Sulfur dioxide}

The "standard" use of ${ }^{210}$ Po ionization does not allow for the sensitive detection of $\mathrm{SO}_{2}$ using $\mathrm{I}^{-}$ions. As outlined in Sect. 3, additional primary ions $\left(\mathrm{IO}_{x}^{-}\right)$formed with our $\mathrm{RF}$ discharge ion source enable $\mathrm{SO}_{2}$ detection as, for example, $\mathrm{ISO}_{3}^{-}\left(\mathrm{m} / z\right.$ 207). In addition, $\mathrm{ISO}_{4}^{-}, \mathrm{SO}_{4}^{-}$and $\mathrm{SO}_{5}^{-}$are also formed and the relative yields are listed in Table 2. Although the underlying ion-molecule reactions resulting in their formation are not fully characterized, based on the observation of $\mathrm{IO}_{3}^{-}$and $\mathrm{IO}_{4}^{-}$in the primary-ion mass spectrum we propose the following scheme (Reactions R14-17).

$$
\begin{aligned}
& \mathrm{SO}_{2}+\mathrm{IO}_{3}^{-} \rightarrow \mathrm{O}_{2}+\mathrm{ISO}_{3}^{-}(m / z 207) \\
& \mathrm{SO}_{2}+\mathrm{IO}_{4}^{-} \rightarrow \mathrm{O}_{2}+\mathrm{ISO}_{4}^{-}(m / z 223) \\
& \mathrm{SO}_{2}+\mathrm{IO}_{3}^{-} \rightarrow \mathrm{IO}+\mathrm{SO}_{4}^{-}(m / z \quad 96) \\
& \mathrm{SO}_{2}+\mathrm{IO}_{4}^{-} \rightarrow \mathrm{IO}+\mathrm{SO}_{5}^{-}(m / z \quad 112)
\end{aligned}
$$

As written, Reactions (R14) and (R16) involving the $\mathrm{IO}_{3}^{-}$anion are exothermic with reaction enthalpies of $\approx-250$ and $-113 \mathrm{~kJ} \mathrm{~mol}^{-1}$, respectively. The enthalpies of formation used to derive these values were taken from the literature: $\Delta \mathrm{H}_{\mathrm{f}}^{298}\left(\mathrm{SO}_{2}\right)=-287 \mathrm{~kJ} \mathrm{~mol}^{-1}$ (Chase, 1998), $\Delta \mathrm{H}_{\mathrm{f}}^{298}(\mathrm{IO})$ $=126 \mathrm{~kJ} \mathrm{~mol}^{-1}\left(\right.$ Goos et al., 2005) and $\Delta \mathrm{H}_{\mathrm{f}}^{298}\left(\mathrm{SO}_{4}^{-}\right)=$ $-738 \mathrm{~kJ} \mathrm{~mol}^{-1}$ (NIST Webbook, 2010) or calculated from other thermodynamic properties. The formation enthalpy for $\mathrm{IO}_{3}^{-}\left(\Delta \mathrm{H}_{\mathrm{f}}^{298}\left(\mathrm{IO}_{3}^{-}\right)=-211 \mathrm{~kJ} \mathrm{~mol}^{-1}\right)$ was calculated from its electron affinity $\left(453.5 \mathrm{~kJ} \mathrm{~mol}^{-1}\right.$; Wen et al., 2011) and the formation enthalpy of $\mathrm{IO}_{3}\left(242 \mathrm{~kJ} \mathrm{~mol}^{-1}\right.$; Goos et al., 2005). The formation enthalpy for $\mathrm{ISO}_{3}^{-}\left(\Delta \mathrm{H}_{\mathrm{f}}^{298}\left(\mathrm{ISO}_{3}^{-}\right)=\right.$ $\left.-752 \mathrm{~kJ} \mathrm{~mol}^{-1}\right)$ was calculated from the $\mathrm{SO}_{3}-\mathrm{I}^{-}$bond strength $\left(161 \mathrm{~kJ} \mathrm{~mol}^{-1}\right.$; Hao et al., 2005) and the formation enthalpies of $\mathrm{I}^{-}\left(-195 \mathrm{kJmol}^{-1}\right.$; Goos et al., 2005) and $\mathrm{SO}_{3}\left(-396 \mathrm{~kJ} \mathrm{~mol}^{-1}\right.$; Goos et al., 2005). In the absence of thermodynamic data for $\mathrm{IO}_{4}^{-}$, we cannot assess the reaction enthalpies for Reactions (R15) and (R17). The iodinecontaining $\mathrm{ISO}_{3}^{-}(\mathrm{m} / \mathrm{z} 207)$ is most specific and suitable for monitoring $\mathrm{SO}_{2}$ with good sensitivity.

\section{Calibration of $\mathrm{SO}_{2}$}

$\mathrm{SO}_{2}$ is calibrated by the addition of a small flow of $\mathrm{SO}_{2}$ from a gas cylinder (1 ppmv in synthetic air, Air Liquide). The true mixing ratio of $\mathrm{SO}_{2}$ flowing from the bottle into the absorption cell at 1 bar pressure was determined via UVabsorption spectroscopy using a white cell and diode array set-up (Wollenhaupt et al., 2000) and an absorption spectrum (290-320 nm) from the literature (Bogumil et al., 2003). The mixing ratio that was determined in this manner was found to agree to within $10 \%$ of the manufacturers specifications. The linearity of the CI-QMS signal with the $\mathrm{SO}_{2}$ mixing ratio (up to $60 \mathrm{ppbv}$ ) is shown as Fig. S4a.

\subsection{Nitryl chloride}

The scheme for detection of $\mathrm{ClNO}_{2}$ using $\mathrm{I}^{-}$ions generated using ${ }^{210} \mathrm{Po}$ is well-established (Osthoff et al., 2008; Thornton et al., 2010). Both $\mathrm{ICl}^{-}\left(\mathrm{m} / \mathrm{z} 162\right.$ and 164) and $\mathrm{IClNO}_{2}^{-}$ $(\mathrm{m} / \mathrm{z} 208$ and 210) are formed, the latter generally preferred to monitor $\mathrm{ClNO}_{2}$ in ambient air owing to potential interference through reactions of other chlorine-containing trace gases forming $\mathrm{ICl}^{-}$.

$$
\begin{aligned}
& \mathrm{ClNO}_{2}+\mathrm{I}^{-} \rightarrow \mathrm{IClNO}_{2}^{-} \\
& \mathrm{ClNO}_{2}+\mathrm{I}^{-} \rightarrow \mathrm{ICl}^{-}+\mathrm{NO}_{2}
\end{aligned}
$$

The same ions are observed during operation with the RF discharge ion source with similar product yields for ${ }^{210} \mathrm{Po}$ as the ones for the RF discharge reported in Table 2.

\section{Calibration of $\mathrm{ClNO}_{2}$}

$\mathrm{ClNO}_{2}$ was calibrated by passing $\mathrm{Cl}_{2}$ (50 ppmv in nitrogen, Air Liquide) over $\mathrm{NaNO}_{2}(30 \mathrm{~g})$ and $\mathrm{NaCl}(10 \mathrm{~g})$ crystals in a glass flask (Thaler et al., 2011). The $\mathrm{ClNO}_{2}$ generation efficiency was found to be improved by moistening the crystals by adding 2-3 drops of water. The gas mixture exiting the glass flask, which contains unreacted $\mathrm{Cl}_{2}, \mathrm{NO}_{2}$ and $\mathrm{ClNO}_{2}$, was diluted in $5 \mathrm{slm}$ air and sampled simultaneously with the CI-QMS and a cavity ring-down spectrometer that detects both $\mathrm{NO}_{2}$ and $\mathrm{ClNO}_{2}$ after thermal decomposition at $420^{\circ} \mathrm{C}$ to $\mathrm{NO}_{2}$ (Thieser et al., 2016). $\mathrm{ClNO}_{2}$ thermograms (Sobanski et al., 2016; Thieser et al., 2016) indicate that, under the flow and pressure conditions of these calibrations, $\mathrm{ClNO}_{2}$ is thermally decomposed to $\mathrm{NO}_{2}$ at $420^{\circ} \mathrm{C}$ (Reaction R20), but there is no significant loss at $200^{\circ} \mathrm{C}$, the TDR temperature of 
the CI-QMS.

$$
\mathrm{ClNO}_{2}+\mathrm{M}\left(420^{\circ} \mathrm{C}\right) \rightarrow \mathrm{Cl}+\mathrm{NO}_{2}+\mathrm{M}
$$

The total uncertainty $(\approx 25 \%)$ associated with the calibration derives from uncertainty in the $\mathrm{NO}_{2}$ cross section used to calculate $\mathrm{NO}_{2}$ mixing ratios in the cavity ring-down spectrometer and the assumption that all $\mathrm{ClNO}_{2}$ is detected as $\mathrm{NO}_{2}$.

\subsection{Hydrogen chloride}

Using the discharge ion source we detect $\mathrm{HCl}$ as $\mathrm{Cl}^{-}, \mathrm{ICl}^{-}$ and $\mathrm{I}(\mathrm{CN}) \mathrm{Cl}^{-}$, presumably via Reactions (R21)-(23).

$$
\begin{aligned}
& \mathrm{HCl}+\mathrm{I}(\mathrm{CN})_{2}^{-} \rightarrow \mathrm{HCN}+\mathrm{I}(\mathrm{CN}) \mathrm{Cl}^{-}(m / z \quad 188 \text { and } 190) \\
& \mathrm{HCl}+\mathrm{ICN}^{-} \rightarrow \mathrm{HCN}+\mathrm{ICl}^{-}(m / z 162 \text { and } 164) \\
& \mathrm{HCl}+\mathrm{CN}^{-} \rightarrow \mathrm{HCN}+\mathrm{Cl}^{-}(m / z 35 \text { and } 37) .
\end{aligned}
$$

Reactions (R22) and (R23) are weakly exothermic with reaction enthalpies of $\approx-25$ and $-73 \mathrm{~kJ} \mathrm{~mol}^{-1}$, respectively. If available, the enthalpies of formation used to derive these values were taken from Goos et al. (2005), $\Delta \mathrm{H}_{\mathrm{f}}^{298}(\mathrm{HCl})=-92, \Delta \mathrm{H}_{\mathrm{f}}^{298}(\mathrm{HCN})=130$, $\Delta \mathrm{H}_{\mathrm{f}}^{298}\left(\mathrm{Cl}^{-}\right)=-234, \Delta \mathrm{H}_{\mathrm{f}}^{298}\left(\mathrm{CN}^{-}\right)=61 \mathrm{~kJ} \mathrm{~mol}^{-1}$, and Refaey and Franklin (1977), $\Delta \mathrm{H}_{\mathrm{f}}^{298}\left(\mathrm{ICl}^{-}\right)=-155 \mathrm{~kJ}$ $\mathrm{mol}^{-1} \cdot \Delta \mathrm{H}_{\mathrm{f}}^{298}\left(\mathrm{ICN}^{-}\right)=92 \mathrm{~kJ} \mathrm{~mol}^{-1}$ was calculated from $\Delta \mathrm{H}_{\mathrm{f}}^{298}(\mathrm{ICN})=222 \mathrm{~kJ} \mathrm{~mol}^{-1}$ (Goos et al., 2005) and the electron affinity of ICl $\left(130 \mathrm{~kJ} \mathrm{~mol}^{-1}\right.$, (Miller et al., 2012). The $\mathrm{I}(\mathrm{CN})_{2}^{-}$ion is stable in an aqueous solution (Chadwick et al., 1980), but a lack of thermodynamic data for it and for $\mathrm{I}(\mathrm{CN}) \mathrm{Cl}^{-}$precludes calculation of the energetics of Reaction (R21).

As $\mathrm{I}(\mathrm{CN}) \mathrm{Cl}^{-}$, formed by reaction of dicyanoiodate anion with $\mathrm{HCl}$ in Reaction (R21), is the most abundant and specific product ion, $\mathrm{HCl}$ is generally monitored at $m / z$ 188. In the absence of interferences, the ratio of signals at $m / z 188$ to $m / z 190$ and $m / z 162$ to $m / z 164$ should be determined by the natural relative abundance of the ${ }^{35} \mathrm{Cl}$ and ${ }^{37} \mathrm{Cl}$ isotopes, which is $\approx 3.13$. Plots of the relative ion signals at $m / z 188$ versus $m / z 190$ and $m / z 162$ versus $m / z 164$ obtained during the CYPHEX campaign are given in Fig. S5. The tight correlation and the slope of 3.09 for the ratio $\mathrm{m} / z 162$ to $\mathrm{m} / \mathrm{z} 164$ is very close to the expected value, indicating that to a good approximation only one trace gas containing one $\mathrm{Cl}$ atom was measured. In contrast, the ratio of $m / z 188$ to $\mathrm{m} / z 190$ is significantly lower than expected, and the correlation displays more scatter. This low ratio indicates that $m / z 190$ suffers from interference from another trace gas. A likely candidate is $\mathrm{HNO}_{3}$, detected as $\mathrm{IHNO}_{3}^{-}$at $m / z$ (Lee et al., 2014). The signals at $m / z 188$ and $m / z 162$ are correlated very well $\left(R^{2}=0.96\right)$ indicating that they both represent $\mathrm{HCl}$ only, as no significant $\mathrm{ClNO}_{2}$ was present during CYPHEX.

\section{Calibration of $\mathrm{HCl}$}

A bottle of gaseous $\mathrm{HCl}$ diluted in $\mathrm{N}_{2}(60 \mathrm{ppmv})$ was used to calibrate the CI-QMS during laboratory operation. The concentration of $\mathrm{HCl}$ was determined using UV-absorption spectroscopy $(184.95 \mathrm{~nm})$ using a cross section of $2.39 \times$ $10^{-19} \mathrm{~cm}^{2}$ molecule ${ }^{-1}$ (Bahou et al., 2001), as described by Zimmermann et al. (2016). Once the sensitivity of the CIQMS to $\mathrm{HCl}$ was established using bottled gas, the output of a laboratory-built permeation source was measured by comparing signals in the CI-QMS at $m / z 188$. The permeation source consisted of a few $\mathrm{mL}$ of concentrated $\mathrm{HCl}$-solution welded into a short length $(4 \mathrm{~cm})$ of $6.35 \mathrm{~mm}$ (OD) PFA tubing, housed in $20 \mathrm{~cm}$ of $12.7 \mathrm{~mm}$ (OD) PFA tubing (at $30^{\circ} \mathrm{C}$ ) through which $50 \mathrm{sccm}$ of air flows. The permeation rate measured was $5.2 \times 10^{-5} \mathrm{sccm}$ with an uncertainty of the $\mathrm{HCl}$ calibration of $10 \%$. The linearity of the CI-QMS signal with the $\mathrm{HCl}$ mixing ratio was characterized in the laboratory $\left(R^{2}=0.99\right)$ and is shown as Fig. S4b.

\section{Dependence of sensitivity on relative humidity}

The CI-QMS sensitivity for the trace gases discussed here is dependent on the amount of water vapour present in the IMR, which will vary with ambient relative humidity (RH). Broadly speaking, we observe a positive dependence of the sensitivity (see Fig. 5) on relative humidity between $0 \%$ and $20 \%$ at $25{ }^{\circ} \mathrm{C}$, with a flattening of the curve between $20 \%$ and $80 \% \mathrm{RH}$. This effect is generally explained by the reactions proceeding predominantly through clustered primary ions, e.g. $\mathrm{I}^{-}\left(\mathrm{H}_{2} \mathrm{O}\right)$, which is observed at $m / z$ 145. Under weak de-clustering conditions, the product ions are also clustered with $\mathrm{H}_{2} \mathrm{O}$, confirming the participation of $\mathrm{I}^{-}\left(\mathrm{H}_{2} \mathrm{O}\right)$. For the $\mathrm{IO}_{3}^{-}$and $\mathrm{I}(\mathrm{CN})_{2}^{-}$primary ions used to detect $\mathrm{SO}_{2}$ and $\mathrm{HCl}$, the water clusters $\mathrm{IO}_{3}^{-}\left(\mathrm{H}_{2} \mathrm{O}\right)_{n}$ and $\mathrm{I}(\mathrm{CN})_{2}^{-}\left(\mathrm{H}_{2} \mathrm{O}\right)_{n}$ are not observed or are very weak, even without de-clustering. We observe that the concentration of $\mathrm{IO}_{3}^{-}$and $\mathrm{I}(\mathrm{CN})_{2}^{-}$in the primary-ion spectra is dependent on the presence of $\mathrm{H}_{2} \mathrm{O}$, which explains the $\mathrm{RH}$ dependence of the sensitivity of detection for $\mathrm{SO}_{2}$ and $\mathrm{HCl}$. All ambient measurements of the trace gases discussed here are therefore corrected for RH effects using calibration curves based on data such as those displayed in Fig. 5. 


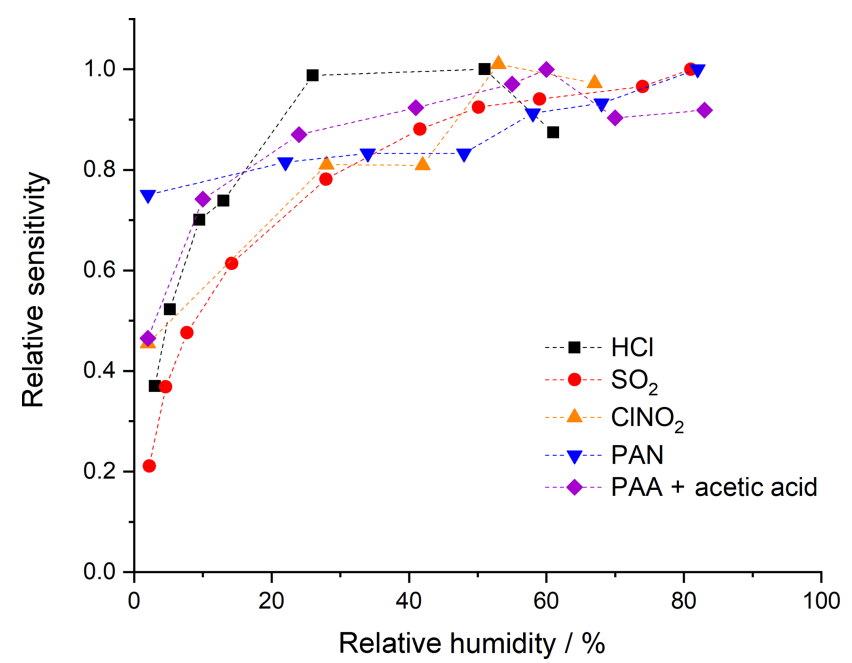

Figure 5. Dependence of the ion signal on the relative humidity (at $25^{\circ} \mathrm{C}$ and 1 bar) of the air sampled. For PAA + acetic acid on $\mathrm{m} / \mathrm{z} 59$ only a combined humidity dependence is given as their contributions to the signal could not reliably be quantified.

\section{Sensitivity, detection limits and total uncertainty}

The total uncertainty of the measurement of any of the trace gases listed above is determined mainly by the uncertainty associated with the calibration method (and its reproducibility) but may also be influenced by, for example, scrubbing efficiency and drifts between background measurements (variable for different field campaigns). The response of the CIQMS to any one trace gas may also vary over a period from days to a few weeks due to drifts in temperature, resolution of the mass spectrometer and degradation of the detector. The sensitivity (i.e. signal in $\mathrm{Hz}$ per pptv of trace gas) depends on the rate coefficient for the reaction between primary ions and trace gases and the yield of product ions. The sensitivity may also depend on relative humidity (abundance of $\mathrm{H}_{2} \mathrm{O}$ clusters) and de-clustering potential (breakup of weak bonds). The limit of detection (LOD) is mainly dependent on variability in the background signal for the respective $m / z$ and can be calculated as 2 times the standard deviation when using synthetic (i.e. hydrocarbon-free) air or when passing the air through the scrubber (as usually performed during field measurements). In the text below (summarized in Table 2), we report sensitivities (in $\mathrm{Hz} \mathrm{pptv}^{-1}$ ) and limits of detection (LOD, $2 \sigma$, in pptv) obtained under typical measurement conditions (configuration iii from Sect. 3) and, when applicable, compare them to values obtained using ${ }^{210} \mathrm{Po}$ as an ion source.

\subsection{PAN, PAA and acetic acid}

When using ${ }^{210} \mathrm{Po}$ as an ion source, an LOD of 3 pptv PAN $(1 \mathrm{~s})$ is achievable, which is adequate for, e.g. airborne operation (Roiger et al., 2011) or flux measurements (Wolfe et al., 2009). The use of the RF discharge for PAN detection results in an increase in background signal (from a few hertz when using ${ }^{210} \mathrm{Po}$ to several hundred hertz when using the RF discharge ion source) even in hydrocarbon-free synthetic air. The LOD calculated from twice the standard deviation of a background measurement during the NOTOMO campaign is $34 \mathrm{pptv}(1 \mathrm{~s})$. The total uncertainty calculated from measurement precision, background subtraction (signal drifts, interpolation) and uncertainty in the calibration method is $15 \%$ \pm 27 pptv. However, the uncertainty of the PAN measurement is highly dependent on the levels and variability of PAA and acetic acid present in the air, as their signal has to be interpolated and subtracted. In ambient air masses, the larger part of the signal at $m / z 59$ with the RF discharge is due to acetic acid, which sometimes displays variability on the timescale of minutes. In this case the uncertainty of the background interpolation and therefore the overall uncertainty of the PAN measurement is drastically increased. This is essentially a selectivity problem, which limits deployment of the instrument for PAN measurements to more polluted regions where PAN mixing ratios regularly exceed $100 \mathrm{pptv}$ and/or high time resolution is not necessary. As described above, the selectivity to PAN can be improved by switching off de-clustering (no acetic acid detection at $m / z 59$ ), which comes with a significant reduction in sensitivity (see below).

In order to differentiate between PAA and acetic acid, the de-clustering voltage has to be modulated between 20 and $2 \mathrm{~V}$. At the lower voltage, only PAA is detected but the resultant high chemical background and worsened sensitivity were found to lead to a poor limit of detection of a few hundred pptv (1 s) (see Table 2), which is about a factor of 100 higher than with use of ${ }^{210} \mathrm{Po}$ (4 pptv in $1 \mathrm{~s}$ ). At the higher potential the LOD would be much better but the sensitivity to acetic acid at $m / z 59$ reduces the selectivity of the measurement. The total uncertainty calculated from measurement precision, background subtraction (signal drifts, interpolation) and uncertainty in the calibration method is $20 \% \pm 39$ pptv.

The LOD for acetic acid at $m / z 59$ is $57 \mathrm{pptv}(1 \mathrm{~s})$ but the selectivity is reduced due to the PAA contribution. The total uncertainty calculated from measurement precision, background subtraction (signal drifts, interpolation) and uncertainty in the calibration method is $15 \% \pm 45 \mathrm{pptv}$.

\section{$6.2 \quad \mathrm{SO}_{2}$}

The sensitivity of the CI-QMS to $\mathrm{SO}_{2}$ reported in Table 2 is dependent on the relative humidity (see Sect. 5) and is especially dependent on the de-clustering voltage, the best signal-to-noise ratio being found at $20 \mathrm{~V}$. Although $\mathrm{HSO}_{4}^{-}$ $(m / z$ 97) has the highest sensitivity of all product ions, we generally monitor the $\mathrm{ISO}_{3}^{-}$ion $(\mathrm{m} / z$ 207) as the background signal is lower and the detection limit improved. Figure S6 displays the correlation between both $\mathrm{m} / \mathrm{z}$ over a period of 4 weeks during the NOTOMO campaign. The correlation co- 
efficient $\left(R^{2}=0.95\right)$ is large, from which we conclude that both $m / z$ can be used to calculate $\mathrm{SO}_{2}$ mixing ratios. The detection limit for $m / z, 207$ is $56 \mathrm{pptv}(1 \mathrm{~s})$ (based on noise in background measurements during the NOTOMO field campaign), which is sufficient to monitor $\mathrm{SO}_{2}$ in lightly polluted areas. At a lower temporal resolution and when monitoring only $\mathrm{ISO}_{3}^{-}$and $\mathrm{I}^{-}$, the LOD can be improved to a few pptv (e.g. in $10 \mathrm{~min}$ ). The total uncertainty, calculated from measurement precision, background subtraction (signal drifts, interpolation) and uncertainty in the calibration method is $20 \% \pm 23$ pptv.

\section{3 $\quad \mathrm{ClNO}_{2}$}

Very good detection limits have been reported (Osthoff et al., 2008; Thornton et al., 2010; Phillips et al., 2012) for the measurement of $\mathrm{ClNO}_{2}$ via I-CIMS using ${ }^{210}$ Po ionization, a result of low background signal at $m / z 208\left(\mathrm{IClNO}_{2}^{-}\right)$and an efficient reaction with $\mathrm{I}^{-}$. Using ${ }^{210} \mathrm{Po}$, Phillips et al. (2012) achieved an LOD $(2 \sigma)$ of 3 pptv ( $1 \mathrm{~s})$, which can be compared to the value of $12 \mathrm{pptv}(1 \mathrm{~s})$ (see Table 2) obtained with the RF discharge ion source, the difference stemming from a higher chemical background signal. With an averaging interval of 5 min the LOD can be reduced to 2-3 pptv. $\mathrm{ClNO}_{2}$ can also be detected as $\mathrm{ICl}^{-}(\mathrm{m} / z, 162$ and 164), which provides higher sensitivity compared to $\mathrm{ICINO}_{2}^{-}$(see Table 2 ) but can suffer from a significant interference due to $\mathrm{HCl}$, which is likely to be present in air masses containing $\mathrm{ClNO}_{2}$. For example, 1 ppbv $\mathrm{HCl}$ contributes a signal at $m / z 162$ which is equivalent to $60 \mathrm{pptv} \mathrm{ClNO}_{2}$ at this $m / z$. Monitoring $\mathrm{ClNO}_{2}$ at $m / z 208$ is more specific, with an equivalent signal due to $1 \mathrm{ppb} \mathrm{HCl}$ of less than $10 \mathrm{pptv}$, which can be accounted for when measuring $\mathrm{HCl}$ in parallel (at $\mathrm{m} / z 188$; see above). It should be noted that the interference at $m / z 162$ is not unique to the RF discharge but has also been observed when using a ${ }^{210}$ Po ionizer (Phillips et al., 2012). The total uncertainty for $\mathrm{ClNO}_{2}$ measurement, calculated from precision, background subtraction (signal drifts, interpolation) and uncertainty in the calibration method, is $30 \% \pm 6 \mathrm{pptv}$.

\subsection{HCl}

Sensitivities and product yields for several ions connected to $\mathrm{HCl}$ detection are reported in Table 2. As $\operatorname{ICl}(m / z 162$ and 164) suffers from a $\mathrm{ClNO}_{2}$ interference (see above) and $\mathrm{Cl}^{-}$( $m / z \quad 35$ and 37) could possibly arise from other Clcontaining species, the more specific ion $\mathrm{I}(\mathrm{CN}) \mathrm{Cl}^{-}(\mathrm{m} / z 188$ and 190) is used to monitor $\mathrm{HCl}$. The LOD for $m / z 188$ is 135 pptv ( $1 \mathrm{~s})$, which can be further improved by extended averaging if high time resolution is not required. The total uncertainty calculated from measurement precision, background subtraction (signal drifts, interpolation), scrubbing efficiency (it takes more time to remove $\mathrm{HCl}$ in the scrubber than, e.g. $\mathrm{SO}_{2}$ ) and uncertainty in the calibration method is $20 \% \pm 72$ pptv.

\section{Application in the field}

Our CI-QMS instrument has been deployed in different ground-based field campaigns including ones at coastal (CYPHEX, 2014), forested (IBAIRN, 2016) and mountain sites (NOTOMO, 2015) in Europe. In the following we present subsets of the data from these campaigns in order to indicate how the instrument with an RF discharge ion source (configuration iii in Sect. 3) performs in the field.

\subsection{CYPHEX 2014}

During CYPHEX (Cyprus Photochemistry Experiment, summer 2014), located at a coastal site on the eastern Mediterranean island of Cyprus, we measured chemically aged air masses with origins in continental Europe (Meusel et al., 2016; Derstroff et al., 2017). A time series of $\mathrm{SO}_{2}$ and $\mathrm{HCl}$ for a 3-week period of the campaign is shown in Fig. 6. $\mathrm{SO}_{2}$ was detected for the first time using the CIQMS during CYPHEX in which observations of covariance between the signal at $m / z 207$ and particulate sulfate provided the first clues to the identity of the mass peak as $\mathrm{ISO}_{3}^{-}$ and indications of sensitivity to $\mathrm{SO}_{2}$. As we had not anticipated CI-QMS sensitivity to $\mathrm{SO}_{2}$, calibration was performed post-campaign. We observed $\mathrm{SO}_{2}$ mixing ratios as high as $11 \mathrm{ppbv}$, the plume-like nature of which strongly suggests nearby point sources such as ship traffic or air masses originating from power plants in continental Europe. Our measurements are consistent with other observations in the coastal Mediterranean boundary layer. Bardouki et al. (2003) found $\mathrm{SO}_{2}$ mixing ratios up to 3 ppbv in Crete (August 2001) and Schembari et al. (2012) report average daily mean values of several ppbv in different western Mediterranean harbours measured in the summers of 2009 and 2010. Kanakidou et al. (2011) conclude that megacities can be hotspots of air pollution in the eastern Mediterranean, with average $\mathrm{SO}_{2}$ mixing ratios of 1 ppbv measured in Crete (1997-1999), 8 ppbv in Istanbul (1998-2008), 10-15 ppbv in Athens (1995-1997) and 48 ppbv in Cairo (1999-2000), where about $70 \%$ originates from industrial activities.

Similar to $\mathrm{SO}_{2}$, the measurement of $\mathrm{HCl}$ was unexpected, the isotopic ratio of $3: 1$ for the signals at $m / z 162$ and 164 $\left(\mathrm{ICl}^{-}\right)$providing evidence that the trace gas measured contained one $\mathrm{Cl}$ atom. The identification of $\mathrm{HCl}$ was confirmed during the campaign, in which a permeation source was built and used to periodically supply $\mathrm{HCl}$ to the CI-QMS. Calibration of the permeation source ensued post-campaign as described in Sect. 4.4. $\mathrm{HCl}$ mixing ratios up to $3 \mathrm{ppbv}$ were observed, which could be attributed to the release of $\mathrm{HCl}$ from sea salt aerosols when polluted air masses from continental Europe reached the coastal site. The covariance between $\mathrm{HCl}$ and $\mathrm{SO}_{2}$ in Fig. 6 suggests that an acid displacement mechanism involving $\mathrm{SO}_{2}$ oxidation to $\mathrm{H}_{2} \mathrm{SO}_{4}$ and transfer of $\mathrm{H}_{2} \mathrm{SO}_{4}$ to aqueous sea salt aerosol was involved. The median value of the $\mathrm{HCl}$ mixing ratio for the CYPHEX cam- 


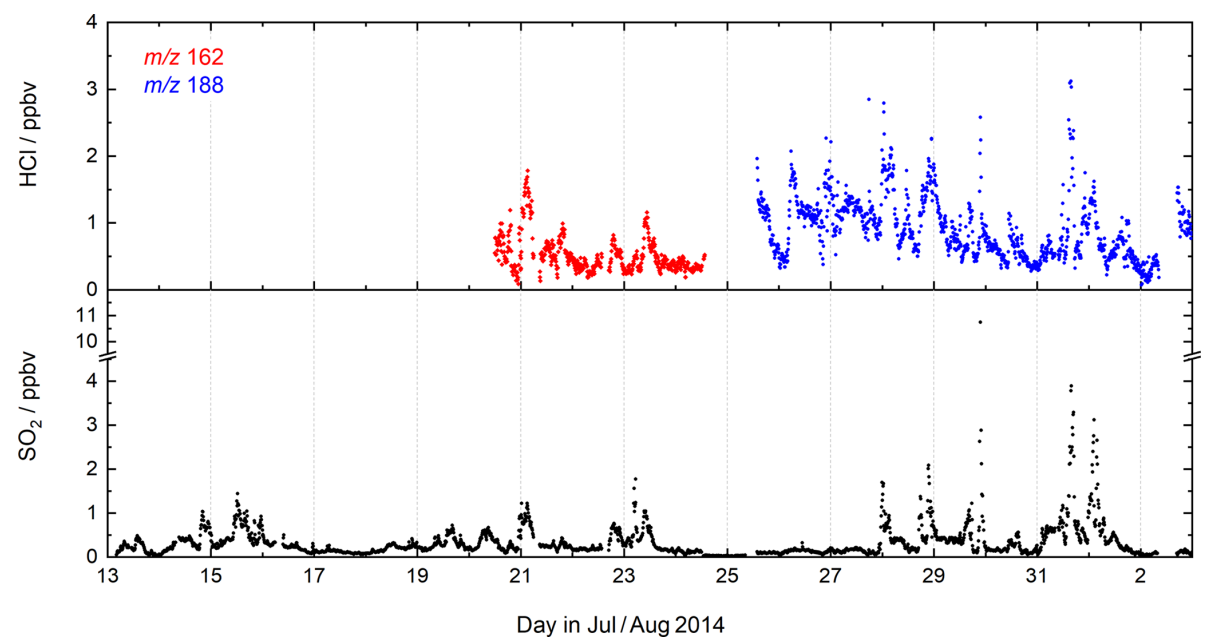

Figure 6. CI-QMS time series of $\mathrm{SO}_{2}$ and $\mathrm{HCl}$ mixing ratios during the CYPHEX field campaign in Cyprus.

paign was $790 \mathrm{pptv}$, which can be compared with reports of median values of 600-700 pptv $\mathrm{HCl}$ over the Atlantic near Europe and values of up to $6 \mathrm{ppbv}$ in the polluted coastal boundary layer on the Isles of Shoals, $10 \mathrm{~km}$ off the southern Maine coast, USA, with an average of 600 pptv (JulyAugust 2004) (Keene et al., 2007, 2009).

\subsection{NOTOMO 2015}

The mountain-site campaign NOTOMO (NOcturnal chemistry at the Taunus Observatory: insights into Mechanisms of Oxidation, summer 2015) took place in a rural location in south-western Germany with significant urban influence (Sobanski et al., 2017). A time series of $\mathrm{SO}_{2}, \mathrm{ClNO}_{2}$ and PAN mixing ratios and the signal at $\mathrm{m} / z 59$ (contributions from acetic and peracetic acid) is displayed in Fig. 7. During NOTOMO, $\mathrm{SO}_{2}$ was monitored as $\mathrm{ISO}_{3^{-}}(\mathrm{m} / z$ 207) and $\mathrm{HSO}_{4}-(m / z$ 97), and a very good correlation between both signals $\left(R^{2}=0.95\right)$ within a period of 4 weeks confirmed that both ions reliably represent the same molecule (see Fig. S6). The $\mathrm{SO}_{2}$ mixing ratios exceeded 1 ppbv on most days, with maximum values up to 5 ppbv. The likely origins of $\mathrm{SO}_{2}$ at this site are emissions from coal-burning power plants in the local Rhine-Main urban conglomeration and the heavily industrialized Ruhr area to the north-west.

$\mathrm{ClNO}_{2}$ was detected during NOTOMO as $\mathrm{ICINO}_{2}^{-}$ $(\mathrm{m} / \mathrm{z} 208$ and 210). Mixing ratios ranged from 0 to $500 \mathrm{pptv}$ and were above 50 pptv during 10 out of 29 campaign nights. High levels of $\mathrm{ClNO}_{2}$ were generally associated with mixed marine and continental air masses from the north-west which had passed over the English Channel and the polluted Ruhr area. The data are consistent with previous measurements (using the CI-QMS equipped with a ${ }^{210}$ Po ionizer) at the same location and similar time of year (Phillips et al., 2012), whereby comparable $\mathrm{ClNO}_{2}$ mixing ratios were observed (see Fig. S7).
We measured PAN at $m / z 59$ and observed mixing ratios generally ranging between 0 and $2 \mathrm{ppbv}$ throughout NOTOMO, occasionally reaching 3 ppbv. PAN levels predominantly peaked in the afternoon, when photochemical activity is usually highest. Compared with results from PARADE (see Fig. S7) in which PAN had been measured with a precursor version of this instrument with a ${ }^{210}$ Po ionizer, frequency and amplitude of the PAN mixing ratios throughout the campaign were very similar. However, due to the high and variable chemical background at $m / z 59$, as already pointed out in Sect. 4.1, the detection limit during NOTOMO was about an order of magnitude worse than in PARADE (see Table 2). As we did not require higher temporal resolution than a few minutes for analysis, this was not a key issue here. The measurements with the RF discharge ion source had adequate sensitivity towards PAN in this moderately polluted region and have the additional advantage over ${ }^{210} \mathrm{Po}$ of simultaneous detection of $\mathrm{SO}_{2}$ and $\mathrm{HCl}$. In contrast, the differentiation between PAA and acetic acid is problematic. During NOTOMO, we were unaware of the sensitivity towards acetic acid at $m / z 59$, and the signal without PAN (i.e. during titration of $\mathrm{CH}_{3} \mathrm{C}(\mathrm{O}) \mathrm{O}_{2}$ with $\mathrm{NO}$ ) was measured with $20 \mathrm{~V}$ declustering only and therefore represents a combined signal of PAA and acetic acid. Although peracetic acid calibration was performed during the campaign, this is not considered reliable because the PAA diffusion source also contains significant amounts of acetic acid. For this reason, we present only an upper limit for acetic acid, ranging between 0 and 8 ppbv. From the PAN-to-PAA ratio calculated for PARADE (about 10) we would also expect several hundred pptv of PAA to be present (see Fig. S7), which would lower this approximate acetic acid mixing ratio significantly. 


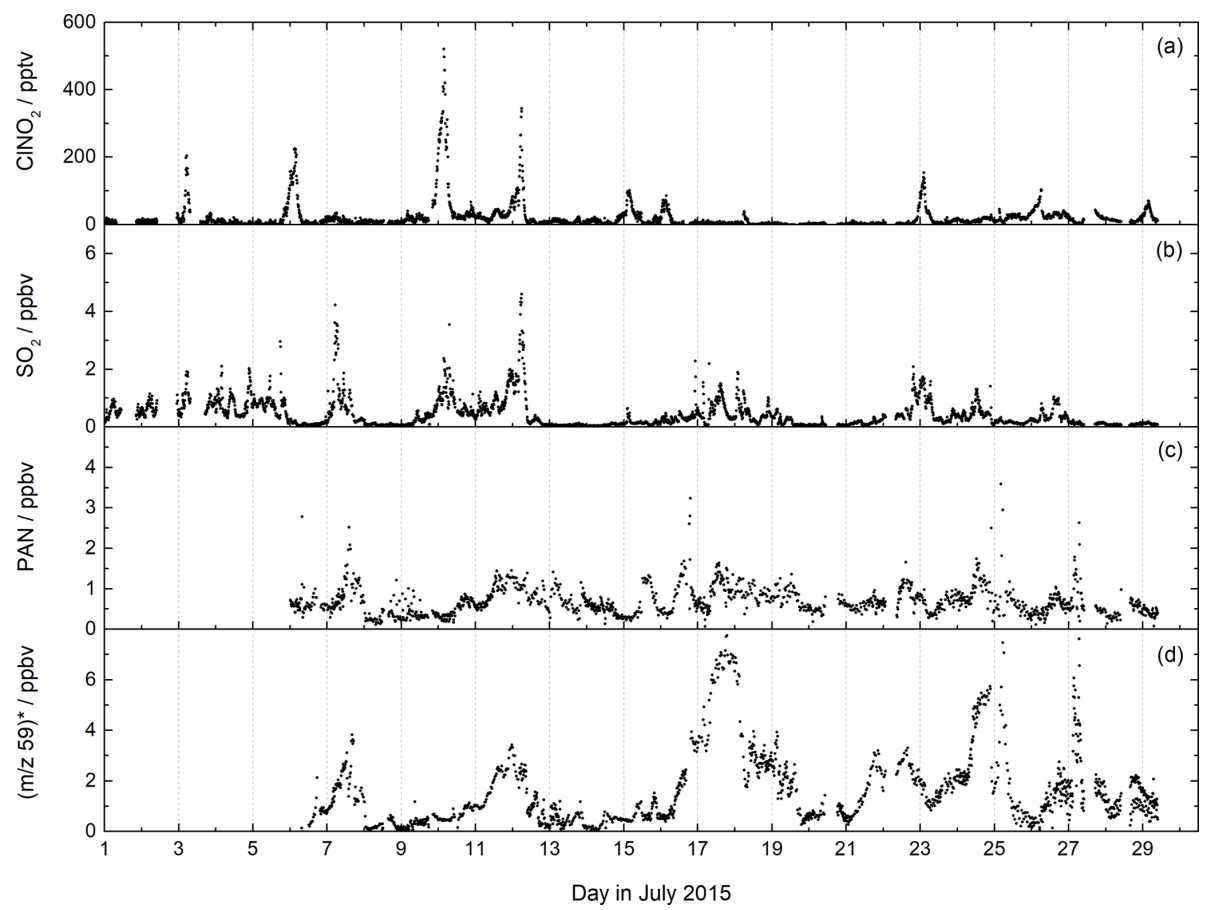

Figure 7. CI-QMS time series of $\mathrm{ClNO}_{2}, \mathrm{SO}_{2}$, PAN mixing ratios and $m / z 59$ during the NOTOMO field campaign in Germany. The signal at $m / z 59$ was converted to ppbv, assuming that it consists only of acetic acid (no peracetic acid). The mixing ratios are therefore only an upper limit. For comparison with the PARADE campaign at the same location see Fig. S7.

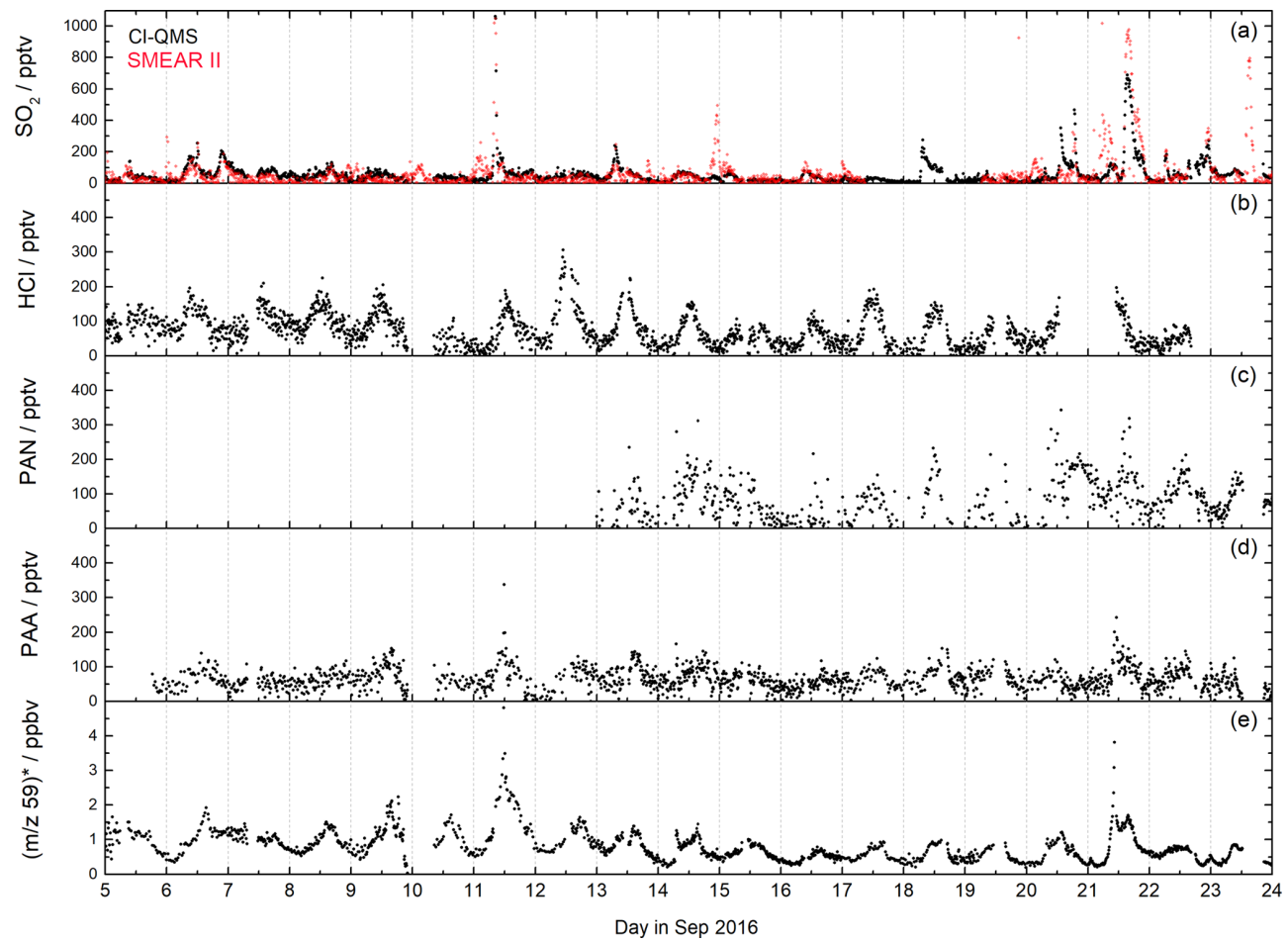

Figure 8. CI-QMS time series of $\mathrm{SO}_{2}, \mathrm{HCl}, \mathrm{PAN}$, PAA mixing ratios and $\mathrm{m} / z 59$ during the IBAIRN campaign, which was undertaken in boreal forest. The red $\mathrm{SO}_{2}$ trace was obtained using a TEI 43 CTL fluorescence analyser (SMEAR II). The signal at $m / z$. 59 was converted to ppbv assuming that it consists only of acetic acid (no peracetic acid). The mixing ratios are therefore only an upper limit. 


\subsection{IBAIRN 2016}

The IBAIRN campaign (Influence of Biosphere-Atmosphere Interactions on the Reactive Nitrogen budget, summer 2016) took place in boreal forest at Hyytiälä, Finland, an area with large biogenic emissions and low- $\mathrm{NO}_{x}$ conditions (Liebmann et al., 2018). The CI-QMS inlet was located at about $6 \mathrm{~m}$ height within the canopy. A time series of $\mathrm{SO}_{2}, \mathrm{HCl}$, PAN, PAA and the signal at $m / z 59$ that has contributions from both acetic and peracetic acid is shown in Fig. 8.

During IBAIRN $\mathrm{SO}_{2}$ was monitored by the CI-QMS as $\mathrm{ISO}_{3}^{-}\left(m / z\right.$ 207) with mixing ratios up to 1 ppbv. $\mathrm{SO}_{2}$ mixing ratios were largest when the air originated from the north-east (point sources like coal-burning power plants in northern Finland and Russia) but only occasionally exceeded $100 \mathrm{pptv}$ in this remote, forested environment. Independent $\mathrm{SO}_{2}$ measurements, using a TEI 43 CTL fluorescence analyser (SMEAR II station, University of Helsinki), were made on a tower at a $16 \mathrm{~m}$ height ( $5 \mathrm{~m}$ distant from the CI-QMS inlet but approximately at canopy height) and allow a direct comparison to be made. The datasets are generally in good agreement (Fig. 8a), although some $\mathrm{SO}_{2}$ plumes were only observed at the higher inlet due to strong gradients in trace gas concentrations resulting from boundary layer dynamics.

$\mathrm{HCl}$ (Fig. 8b) was measured as $\mathrm{I}(\mathrm{CN}) \mathrm{Cl}^{-}(\mathrm{m} / z 188$ and 190 ) with mixing ratios up to 300 pptv showing a distinct diurnal profile with a maximum in the afternoon, which reflects temperature-dependent changes in partitioning between the gas phase and particle phase in which $\mathrm{HCl}$ is converted into $\mathrm{NH}_{4} \mathrm{Cl}$.

The combined PAA and acetic acid signal at $m / z 59$ obtained with de-clustering at $20 \mathrm{~V}$ (Fig. 8e) displays the diurnal profile expected from photochemically generated trace gases with night-time depositional losses. However, as explained in Sect. 7.2, we cannot easily separate the contribution to the signal from PAA and acetic acid. When NO is added (see Fig. S3), the signal at $m / z 59$ with low declustering is due to PAA only (Fig. 8d), but the PAA detection limit is poor due to a low sensitivity and elevated and variable background signal during zeroing. The PAA contribution to the total signal at $m / z 59$ is likely to be substantial but cannot be calculated as the sensitivity of the CI-QMS to PAA during de-clustering (Fig. 8e) is unknown, a result of the presence of unknown amounts of acetic acid in the PAA diffusion source. The use of a ${ }^{210} \mathrm{Po}$ ionizer would have greatly improved the PAN (see Fig. 8c) and PAA data quality, as evidenced by the PAN and PAA measurements reported for the same location during 2010 (Phillips et al., 2013; Crowley et al., 2018).

\section{Conclusions}

The CI-QMS with an RF discharge ion source is a promising alternative to similar instruments using ${ }^{210} \mathrm{Po}$-based ion sources and can be deployed in environments for which per- mission to use ${ }^{210} \mathrm{Po}$ may be difficult or impossible to obtain or to which transportation of ${ }^{210} \mathrm{Po}$ is not feasible. The use of the RF discharge results in an extension of the established detection schemes (e.g. for $\mathrm{ClNO}_{2}$ and PAN) using $\mathrm{I}^{-}$ions, and we have identified ion schemes involving $\mathrm{IO}_{x}^{-}$ and $\mathrm{I}(\mathrm{CN})_{x}^{-}$primary ions that additionally enable detection of $\mathrm{SO}_{2}$ and $\mathrm{HCl}$. Detection limits $(2 \sigma, 1 \mathrm{~s}$ integration) are 56 pptv for $\mathrm{SO}_{2}, 135$ pptv for $\mathrm{HCl}$ and 12 pptv for $\mathrm{ClNO}_{2}$, which makes the CI-QMS a useful tool for investigation of atmospheric processes related to sulfur and chlorine chemistry. Application of the instrument with the RF discharge ion source for PAN detection is limited to polluted environments where mixing ratios usually exceed a hundred pptv and a high temporal resolution is not needed. This restriction is mainly due to a background count rate that is higher by $1-2$ orders of magnitude compared to the use of ${ }^{210} \mathrm{Po}$ and due to a strong dependence of the measurement uncertainty on the variability of the subtracted interpolated background signal (consisting of PAA and acetic acid). A PAN detection limit (in the absence of PAA and acetic acid) of 34 pptv (1 s) was obtained, though this value will rarely be reached in boundary layer air masses where acetic acid and peracetic acid are abundant. Similarly, while sensitive detection of PAA (requiring de-clustering) is precluded by the detection of acetic acid at the same $m / z$, the selective detection of acetic acid is uncertain due to the contribution of PAA.

The deployment of the CI-QMS with RF discharge and its advantages and disadvantages compared to instruments using ${ }^{210}$ Po-based ionization are illustrated in three campaign datasets, which demonstrate its potential to monitor trace gases at mixing ratios ranging from a few tens of pptv to a few ppbv. If the scientific focus is on PAA and PAN, the RFdischarge-based CI-QMS is clearly disadvantaged compared to the more selective and sensitive ${ }^{210}$ Po-based ionization. On the other hand, the potential to measure $\mathrm{ClNO}_{2}$ without logistical obstacles related to transport and (mobile) operation of radioactive sources and the added benefit of simultaneous measurement of $\mathrm{HCl}$ and $\mathrm{SO}_{2}$ may in some instances tip the balance in its favour.

Data availability. The datasets presented in the field studies are archived and distributed through the KEEPER service of the Max Planck Digital Library (https://keeper.mpdl.mpg.de, last acess: 25 March 2019). Details required to access the data will be granted subsequent to agreeing to the relevant data protocol. We are grateful for the provision of automated $\mathrm{SO}_{2}$ measurement data from the SMEAR II site in Hyytiälä (Junninen et al., 2009).

Supplement. The supplement related to this article is available online at: https://doi.org/10.5194/amt-12-1935-2019-supplement. 
Author contributions. PGE developed and tested the RF discharge ion source in the laboratory, deployed the CI-QMS during the NOTOMO and IBAIRN campaigns, evaluated the field data and wrote the paper. FH and GS helped to design and modify the CI-QMS for the constant pressure and RF discharge operations. JNC and JL designed the field campaigns and contributed to the paper; GJP operated the CI-QMS during CYPHEX and helped evaluate the data.

Competing interests. The authors declare that they have no conflict of interest.

Acknowledgements. We thank the Cyprus Ministry of Defence for the use of the base of the Cypriot National Guard at Ineia and the generous assistance of the Lara Naval Observatory staff during the CYPHEX campaign. Our thanks also go to the Department of Labour Inspection of Cyprus for helping us set up the campaign. We thank Heinz Bingemer for logistical support and use of the facilities at the Taunus Observatory during the NOTOMO campaign. We are grateful to the technical staff of SMEAR II station for technical support and ENVRIplus for partial financial support of the IBAIRN campaign. We thank Jan Schuladen for his technical assistance with the CI-QMS and the design of the TDR. We thank Thomas Klüpfel and Jonathan Williams at the Max Planck Institute, Mainz, for the loan of a $\mathrm{CO}_{2}$ detector (LI-COR).

The article processing charges for this open-access publication were covered by the Max Planck Society.

Review statement. This paper was edited by Bin Yuan and reviewed by two anonymous referees.

\section{References}

Atkinson, R., Baulch, D. L., Cox, R. A., Crowley, J. N., Hampson, R. F., Hynes, R. G., Jenkin, M. E., Rossi, M. J., and Troe, J.: Evaluated kinetic and photochemical data for atmospheric chemistry: Volume I - gas phase reactions of $\mathrm{O}_{\mathrm{x}}, \mathrm{HO}_{\mathrm{x}}$, $\mathrm{NO}_{\mathrm{x}}$ and $\mathrm{SO}_{\mathrm{x}}$ species, Atmos. Chem. Phys., 4, 1461-1738, https://doi.org/10.5194/acp-4-1461-2004, 2004.

Atkinson, R., Baulch, D. L., Cox, R. A., Crowley, J. N., Hampson, R. F., Hynes, R. G., Jenkin, M. E., Rossi, M. J., Troe, J., and IUPAC Subcommittee: Evaluated kinetic and photochemical data for atmospheric chemistry: Volume II - gas phase reactions of organic species, Atmos. Chem. Phys., 6, 3625-4055, https://doi.org/10.5194/acp-6-3625-2006, 2006.

Awtrey, A. D. and Connick, R. E.: The absorption spectra of $\mathrm{I}_{2}, \mathrm{I}_{3}^{-}, \mathrm{I}^{-}, \mathrm{IO}_{3}^{-}, \mathrm{S}_{4} \mathrm{O}_{6}^{-}$and $\mathrm{S}_{2} \mathrm{O}_{3}^{-}$. Heat of the reaction $\mathrm{I}_{3}^{-}=\mathrm{I}_{2}+\mathrm{I}^{-}$, J. Am. Chem. Soc., 73, 1842-1843, https://doi.org/10.1021/ja01148a504, 1951.

Bahou, M., Chung, C. Y., Lee, Y. P., Cheng, B. M., Yung, Y. L., and Lee, L. C.: Absorption cross sections of $\mathrm{HCl}$ and $\mathrm{DCl}$ at 135-232 nanometers: Implications for photodissociation on Venus, Astrophys. J., 559, L179-L182, 2001.
Bannan, T. J., Booth, A. M., Bacak, A., Muller, J. B. A., Leather, K. E., Le Breton, M., Jones, B., Young, D., Coe, H., Allan, J., Visser, S., Slowik, J. G., Furger, M., Prevot, A. S. H., Lee, J., Dunmore, R. E., Hopkins, J. R., Hamilton, J. F., Lewis, A. C., Whalley, L. K., Sharp, T., Stone, D., Heard, D. E., Fleming, Z. L., Leigh, R., Shallcross, D. E., and Percival, C. J.: The first UK measurements of nitryl chloride using a chemical ionization mass spectrometer in central London in the summer of 2012, and an investigation of the role of $\mathrm{Cl}$ atom oxidation, J. Geophys. Res.-Atmos., 120, 5638-5657, https://doi.org/10.1002/2014jd022629, 2015.

Bardouki, H., Berresheim, H., Vrekoussis, M., Sciare, J., Kouvarakis, G., Oikonomou, K., Schneider, J., and Mihalopoulos, N.: Gaseous (DMS, MSA, $\mathrm{SO}_{2}, \mathrm{H}_{2} \mathrm{SO}_{4}$ and DMSO) and particulate (sulfate and methanesulfonate) sulfur species over the northeastern coast of Crete, Atmos. Chem. Phys., 3, 1871-1886, https://doi.org/10.5194/acp-3-1871-2003, 2003.

Bayram, S. B. and Freamat, M. V.: Vibrational spectra of N-2: An advanced undergraduate laboratory in atomic and molecular spectroscopy, Am. J. Phys., 80, 664-669, https://doi.org/10.1119/1.4722793, 2012.

Behnke, W., George, C., Scheer, V., and Zetzsch, C.: Production and decay of $\mathrm{ClNO}_{2}$ from the reaction of gaseous $\mathrm{N}_{2} \mathrm{O}_{5}$ with $\mathrm{NaCl}$ solution: Bulk and aerosol experiments, J. Geophys. Res.Atmos., 102, 3795-3804, 1997.

Bogumil, K., Orphal, J., Homann, T., Voigt, S., Spietz, P., Fleischmann, O. C., Vogel, A., Hartmann, M., Kromminga, H., Bovensmann, H., Frerick, J., and Burrows, J. P.: Measurements of molecular absorption spectra with the SCIAMACHY preflight model: instrument characterization and reference data for atmospheric remote-sensing in the $230-2380 \mathrm{~nm}$ region, J. Photoch. Photobio. A, 157, 167-184, https://doi.org/10.1016/s10106030(03)00062-5, 2003.

Chadwick, B. M., Long, D. A., and Qureshi, S. U.: The Raman and infra-red spectra of the dicyanoiodate(I) ion, J. Raman Spectrosc., 9, 1-4, https://doi.org/10.1002/jrs.1250090103, 1980.

Chase Jr., M. W.: NIST-JANAF Themochemical Tables, Fourth Edition, J. Phys. Chem. Ref. Data, Monograph 9, 1-1951, 1998.

Crowley, J. N., Pouvesle, N., Phillips, G. J., Axinte, R., Fischer, H., Petäjä, T., Nölscher, A., Williams, J., Hens, K., Harder, H., Martinez-Harder, M., Novelli, A., Kubistin, D., Bohn, B., and Lelieveld, J.: Insights into $\mathrm{HO} x$ and $\mathrm{RO}_{x}$ chemistry in the boreal forest via measurement of peroxyacetic acid, peroxyacetic nitric anhydride (PAN) and hydrogen peroxide, Atmos. Chem. Phys., 18, 13457-13479, https://doi.org/10.5194/acp-18-134572018, 2018.

Dentener, F. J. and Crutzen, P. J.: Reaction of $\mathrm{N}_{2} \mathrm{O}_{5}$ on tropospheric aerosols - Impact on the global distributions of $\mathrm{NO}_{X}, \mathrm{O}_{3}$, and OH, J. Geophys. Res.-Atmos., 98, 7149-7163, 1993.

Derstroff, B., Hüser, I., Bourtsoukidis, E., Crowley, J. N., Fischer, H., Gromov, S., Harder, H., Janssen, R. H. H., Kesselmeier, J., Lelieveld, J., Mallik, C., Martinez, M., Novelli, A., Parchatka, U., Phillips, G. J., Sander, R., Sauvage, C., Schuladen, J., Stönner, C., Tomsche, L., and Williams, J.: Volatile organic compounds (VOCs) in photochemically aged air from the eastern and western Mediterranean, Atmos. Chem. Phys., 17, 9547-9566, https://doi.org/10.5194/acp-17-9547-2017, 2017.

Faxon, C. B., Bean, J. K., and Hildebrandt Ruiz, L.: Inland Concentrations of $\mathrm{Cl}_{2}$ and $\mathrm{ClNO}_{2}$ in Southeast Texas Suggest Chlorine Chemistry Significantly Contributes 
to Atmospheric Reactivity, Atmosphere, 6, 1487-1506, https://doi.org/10.3390/atmos6101487, 2015.

Flocke, F. M., Weinheimer, A. J., Swanson, A. L., Roberts, J. M., Schmitt, R., and Shertz, S.: On the measurement of PANs by gas chromatography and electron capture detection, J. Atmos. Chem., 52, 19-43, 2005.

Friedrich, N.: Development and characterisation of two methods for the wet-chemical calibration of peracetic acid for chemical ionisation mass-spectrometry (in German), MSc, Inorganic and analytical chemistry, Johannes Gutenberg Universität Mainz, Mainz, 2015.

Furgeson, A., Mielke, L. H., Paul, D., and Osthoff, H. D.: A photochemical source of peroxypropionic and peroxyisobutanoic nitric anhydride, Atmos. Env., 45, 5025-5032, 2011.

Goos, E., Burcat, A., and Ruscic, B.: Extended Third Millennium Ideal Gas and Condensed Phase Thermochemical Database for Combustion with Updates from Active Thermochemical Tables: Update of "Third Millennium Ideal Gas and Condensed Phase Thermochemical Database for Combustion with Updates from Active Thermochemical Tables by Alexander Burcat and Branko Ruscic", Report ANL 05/20 and TAE 960 TechnionIIT, Aerospace Engineering, and Argonne National Laboratory, Chemistry Division, September 2005., 2005.

Hao, C. T., Gilbert, T. M., and Sunderlin, L. S.: The bond dissociation energies of $\mathrm{SO}_{3}-\mathrm{X}^{-}(\mathrm{X}=\mathrm{F}, \mathrm{Cl}, \mathrm{Br}$, and I), Can. J. Chem., 83, 2013-2019, 2005.

Huey, L. G.: Measurement of trace atmospheric species by chemical ionization mass spectrometry: Speciation of reactive nitrogen and future directions, Mass Spectrom. Rev., 26, 166-184, https://doi.org/10.1002/mas.20118, 2007.

Huey, L. G., Hanson, D. R., and Howard, C. J.: Reactions of Sf6and I- with Atmospheric Trace Gases, J. Phys. Chem., 99, 50015008, 1995.

IUPAC: Task Group on Atmospheric Chemical Kinetic Data Evaluation, (Ammann, M., Cox, R. A., Crowley, J. N., Herrmann, H., Jenkin, M. E., McNeill, V. F., Mellouki, A., Rossi, M. J., Troe, J. and Wallington, T. J.), available at: http://iupac.pole-ether.fr/ index.html (last access: January 2019), 2018.

Jost, C., Sprung, D., Kenntner, T., and Reiner, T.: Atmospheric pressure chemical ionization mass spectrometry for the detection of tropospheric trace gases: the influence of clustering on sensitivity and precision, Int. J. Mass Spectrom., 223, 771-782, https://doi.org/10.1016/S1387-3806(02)00963-6, 2003.

Junninen, H., Lauri, A., Keronen, P., Aalto, P., Hiltunen, V., Hari, P., and Kulmala, M.: Smart-SMEAR: on-line data exploration and visualization tool for SMEAR stations, Boreal Environ. Res., 14, 447-457, 2009.

Kanakidou, M., Mihalopoulos, N., Kindap, T., Im, U., Vrekoussis, M., Gerasopoulos, E., Dermitzaki, E., Unal, A., Kocak, M., Markakis, K., Melas, D., Kouvarakis, G., Youssef, A. F., Richter, A., Hatzianastassiou, N., Hilboll, A., Ebojie, F., Wittrock, F., von Savigny, C., Burrows, J. P., Ladstaetter-Weissenmayer, A., and Moubasher, H.: Megacities as hot spots of air pollution in the East Mediterranean, Atmos. Environ., 45, 1223-1235, https://doi.org/10.1016/j.atmosenv.2010.11.048, 2011.

Keene, W. C., Stutz, J., Pszenny, A. A. P., Maben, J. R., Fischer, E. V., Smith, A. M., von Glasow, R., Pechtl, S., Sive, B. C., and Varner, R. K.: Inorganic chlorine and bromine in coastal
New England air during summer, J. Geophys. Res.-Atmos., 112, D10s12, https://doi.org/10.1029/2006jd007689, 2007.

Keene, W. C., Long, M. S., Pszenny, A. A. P., Sander, R., Maben, J. R., Wall, A. J., O’Halloran, T. L., Kerkweg, A., Fischer, E. V., and Schrems, O.: Latitudinal variation in the multiphase chemical processing of inorganic halogens and related species over the eastern North and South Atlantic Oceans, Atmos. Chem. Phys., 9, 7361-7385, https://doi.org/10.5194/acp-9-7361-2009, 2009.

Kürten, A., Rondo, L., Ehrhart, S., and Curtius, J.: Performance of a corona ion source for measurement of sulfuric acid by chemical ionization mass spectrometry, Atmos. Meas. Tech., 4, 437-443, https://doi.org/10.5194/amt-4-437-2011, 2011.

LaFranchi, B. W., Wolfe, G. M., Thornton, J. A., Harrold, S. A., Browne, E. C., Min, K. E., Wooldridge, P. J., Gilman, J. B., Kuster, W. C., Goldan, P. D., de Gouw, J. A., McKay, M., Goldstein, A. H., Ren, X., Mao, J., and Cohen, R. C.: Closing the peroxy acetyl nitrate budget: observations of acyl peroxy nitrates (PAN, PPN, and MPAN) during BEARPEX 2007, Atmos. Chem. Phys., 9, 7623-7641, https://doi.org/10.5194/acp-9-7623-2009, 2009.

Lazrus, A. L., Kok, G. L., Lind, J. A., Gitlin, S. N., Heikes, B. G., and Shetter, R. E.: Automated Fluorometric Method for Hydrogen-Peroxide in Air, Anal. Chem., 58, 594-597, 1986.

Le Breton, M., McGillen, M. R., Muller, J. B. A., Bacak, A., Shallcross, D. E., Xiao, P., Huey, L. G., Tanner, D., Coe, H., and Percival, C. J.: Airborne observations of formic acid using a chemical ionization mass spectrometer, Atmos. Meas. Tech., 5, 30293039, https://doi.org/10.5194/amt-5-3029-2012, 2012.

Lee, B. H., Lopez-Hilfiker, F. D., Mohr, C., Kurten, T., Worsnop, D. R., and Thornton, J. A.: An Iodide-Adduct HighResolution Time-of-Flight Chemical-Ionization Mass Spectrometer: Application to Atmospheric Inorganic and Organic Compounds, Environ. Sci. Technol., 48, 6309-6317, https://doi.org/10.1021/es500362a, 2014.

Lelieveld, J. and Crutzen, P. J.: Influences of Cloud Photochemical Processes on Tropospheric Ozone, Nature, 343, 227-233, 1990.

Liebmann, J., Karu, E., Sobanski, N., Schuladen, J., Ehn, M., Schallhart, S., Quéléver, L., Hellen, H., Hakola, H., Hoffmann, T., Williams, J., Fischer, H., Lelieveld, J., and Crowley, J. N.: Direct measurement of NO3 radical reactivity in a boreal forest, Atmos. Chem. Phys., 18, 3799-3815, https://doi.org/10.5194/acp18-3799-2018, 2018.

Lofthus, A. and Krupenie, P. H.: Spectrum of molecular nitrogen, J. Phys. Chem. Ref. Data, 6, 113-307, https://doi.org/10.1063/1.555546, 1977.

McNeill, V. F., Patterson, J., Wolfe, G. M., and Thornton, J. A.: The effect of varying levels of surfactant on the reactive uptake of $\mathrm{N}_{2} \mathrm{O}_{5}$ to aqueous aerosol, Atmos. Chem. Phys., 6, 1635-1644, https://doi.org/10.5194/acp-6-1635-2006, 2006.

Meusel, H., Kuhn, U., Reiffs, A., Mallik, C., Harder, H., Martinez, M., Schuladen, J., Bohn, B., Parchatka, U., Crowley, J. N., Fischer, H., Tomsche, L., Novelli, A., Hoffmann, T., Janssen, R. H. H., Hartogensis, O., Pikridas, M., Vrekoussis, M., Bourtsoukidis, E., Weber, B., Lelieveld, J., Williams, J., Pöschl, U., Cheng, Y., and $\mathrm{Su}, \mathrm{H}$.: Daytime formation of nitrous acid at a coastal remote site in Cyprus indicating a common ground source of atmospheric HONO and NO, Atmos. Chem. Phys., 16, 14475-14493, https://doi.org/10.5194/acp-16-14475-2016, 2016. 
Mielke, L. H. and Osthoff, H. D.: On quantitative measurements of peroxycarboxylic nitric anhydride mixing ratios by thermal dissociation chemical ionization mass spectrometry, Int. J. Mass Spectrom., 310, 1-9, https://doi.org/10.1016/j.ijms.2011.10.005, 2012.

Mielke, L. H., Furgeson, A., and Osthoff, H. D.: Observation of $\mathrm{CINO}_{2}$ in a mid-continental urban environment, Environ. Sci. Technol., 45, 8889-8896, https://doi.org/10.1021/es201955u, 2011.

Miller, E. M., Sheps, L., Lu, Y. J., Case, A. S., McCoy, A. B., and Lineberger, W. C.: New view of the ICN A continuum using photoelectron spectroscopy of ICN, J. Chem. Phys., 136, 044313, https://doi.org/10.1063/1.3679170, 2012.

Molina, M. J., Tso, T. L., Molina, L. T., and Wang, F. C. Y.: Antarcctic stratospheric chemistry of chlorine nitrate, hydrogen chloride and ice - Release of active chlorine, Science, 238, 1253-1257, https://doi.org/10.1126/science.238.4831.1253, 1987.

Moxim, W. J., Levy, H., and Kasibhatla, P. S.: Simulated global tropospheric PAN: Its transport and impact on NOx, J. Geophys. Res.-Atmos., 101, 12621-12638, 1996.

Neuman, J. A., Trainer, M., Brown, S. S., Min, K. E., Nowak, J. B., Parrish, D. D., Peischl, J., Pollack, I. B., Roberts, J. M., Ryerson, T. B., and Veres, P. R.: HONO emission and production determined from airborne measurements over the Southeast US, J. Geophys. Res.-Atmos., 121, 9237-9250, https://doi.org/10.1002/2016jd025197, 2016.

NIST Webbook: National Institute of Standards and Technology, available at: http://webbook.nist.gov (last access: January 2019), 2010.

Osthoff, H. D., Roberts, J. M., Ravishankara, A. R., Williams, E. J., Lerner, B. M., Sommariva, R., Bates, T. S., Coffman, D., Quinn, P. K., Dibb, J. E., Stark, H., Burkholder, J. B., Talukdar, R. K., Meagher, J., Fehsenfeld, F. C., and Brown, S. S.: High levels of nitryl chloride in the polluted subtropical marine boundary layer, Nat. Geosci., 1, 324-328, 2008.

Phillips, G. J., Tang, M. J., Thieser, J., Brickwedde, B., Schuster, G., Bohn, B., Lelieveld, J., and Crowley, J. N.: Significant concentrations of nitryl chloride observed in rural continental Europe associated with the influence of sea salt chloride and anthropogenic emissions, Geophys. Res. Lett., 39, L10811, https://doi.org/10.1029/2012GL051912, 2012.

Phillips, G. J., Pouvesle, N., Thieser, J., Schuster, G., Axinte, R., Fischer, H., Williams, J., Lelieveld, J., and Crowley, J. N.: Peroxyacetyl nitrate (PAN) and peroxyacetic acid (PAA) measurements by iodide chemical ionisation mass spectrometry: first analysis of results in the boreal forest and implications for the measurement of PAN fluxes, Atmos. Chem. Phys., 13, 11291139, https://doi.org/10.5194/acp-13-1129-2013, 2013.

Phillips, G. J., Thieser, J., Tang, M., Sobanski, N., Schuster, G., Fachinger, J., Drewnick, F., Borrmann, S., Bingemer, H., Lelieveld, J., and Crowley, J. N.: Estimating $\mathrm{N}_{2} \mathrm{O}_{5}$ uptake coefficients using ambient measurements of $\mathrm{NO}_{3}, \mathrm{~N}_{2} \mathrm{O}_{5}, \mathrm{ClNO}_{2}$ and particle-phase nitrate, Atmos. Chem. Phys., 16, 13231-13249, https://doi.org/10.5194/acp-16-13231-2016, 2016.

Priestley, M., le Breton, M., Bannan, T. J., Worrall, S. D., Bacak, A., Smedley, A. R. D., Reyes-Villegas, E., Mehra, A., Allan, J., Webb, A. R., Shallcross, D. E., Coe, H., and Percival, C. J.: Observations of organic and inorganic chlorinated compounds and their contribution to chlorine radical concentrations in an urban environment in northern Europe during the wintertime, Atmos. Chem. Phys., 18, 13481-13493, https://doi.org/10.5194/acp-1813481-2018, 2018.

Refaey, K. M. A. and Franklin, J. L.: Endoergic ion-molecule collision processes of negaive ions. 6. Collisions of $\mathrm{I}^{-}$ on $(\mathrm{CN})_{2}$ and $\mathrm{NOCl}$, Int. J. Mass Spectrom., 23, 13-20, https://doi.org/10.1016/0020-7381(77)80002-8, 1977.

Riedel, T. P., Bertram, T. H., Crisp, T. A., Williams, E. J., Lerner, B. M., Vlasenko, A., Li, S. M., Gilman, J., de Gouw, J., Bon, D. M., Wagner, N. L., Brown, S. S., and Thornton, J. A.: Nitryl Chloride and Molecular Chlorine in the Coastal Marine Boundary Layer, Environ. Sci. Technol., 46, 10463-10470, https://doi.org/10.1021/es204632r, 2012.

Roiger, A., Aufmhoff, H., Stock, P., Arnold, F., and Schlager, H.: An aircraft-borne chemical ionization - ion trap mass spectrometer (CI-ITMS) for fast PAN and PPN measurements, Atmos. Meas. Tech., 4, 173-188, https://doi.org/10.5194/amt-4173-2011, 2011.

Schembari, C., Cavalli, F., Cuccia, E., Hjorth, J., Calzolai, G., Perez, N., Pey, J., Prati, P., and Raes, F.: Impact of a European directive on ship emissions on air quality in Mediterranean harbours, Atmos. Environ., 61, 661-669, https://doi.org/10.1016/j.atmosenv.2012.06.047, 2012.

Skalny, J. D., Horvath, G., and Mason, N. L.: Mass spectrometric analysis of small negative ions $(\mathrm{e} / \mathrm{m}<100)$ produced by Trichel pulse negative corona discharge fed by ozonised air, J. Optoelectron. Adv. M., 9, 887-893, 2007.

Slusher, D. L., Huey, L. G., Tanner, D. J., Flocke, F. M., and Roberts, J. M.: A thermal dissociation-chemical ionization mass spectrometry (TD-CIMS) technique for the simultaneous measurement of peroxyacyl nitrates and dinitrogen pentoxide, J. Geophys. Res.-Atmos., 109, D19315, https://doi.org/10.1029/2004JD004670, 2004.

Sobanski, N., Schuladen, J., Schuster, G., Lelieveld, J., and Crowley, J. N.: A five-channel cavity ring-down spectrometer for the detection of $\mathrm{NO}_{2}, \mathrm{NO}_{3}, \mathrm{~N}_{2} \mathrm{O}_{5}$, total peroxy nitrates and total alkyl nitrates, Atmos. Meas. Tech., 9, 5103-5118, https://doi.org/10.5194/amt-9-5103-2016, 2016.

Sobanski, N., Thieser, J., Schuladen, J., Sauvage, C., Song, W., Williams, J., Lelieveld, J., and Crowley, J. N.: Day and nighttime formation of organic nitrates at a forested mountain site in south-west Germany, Atmos. Chem. Phys., 17, 4115-4130, https://doi.org/10.5194/acp-17-4115-2017, 2017.

Svarnas, P.: Vibrational temperature of excited nitrogen molecules detected in a $13.56 \mathrm{MHz}$ electrical discharge by sheath-side optical emission spectroscopy, Plasma Sci. Technol., 15, 891-895, https://doi.org/10.1088/1009-0630/15/9/11, 2013.

Thaler, R. D., Mielke, L. H., and Osthoff, H. D.: Quantification of nitryl chloride at part per trillion mixing ratios by thermal dissociation cavity ring-down spectroscopy, Anal. Chem., 83, 27612766, https://doi.org/10.1021/ac200055z, 2011.

Tham, Y. J., Wang, Z., Li, Q., Yun, H., Wang, W., Wang, X., Xue, L., Lu, K., Ma, N., Bohn, B., Li, X., Kecorius, S., Größ, J., Shao, M., Wiedensohler, A., Zhang, Y., and Wang, T.: Significant concentrations of nitryl chloride sustained in the morning: investigations of the causes and impacts on ozone production in a polluted region of northern China, Atmos. Chem. Phys., 16, 14959-14977, https://doi.org/10.5194/acp-16-14959-2016, 2016. 
Thieser, J., Schuster, G., Schuladen, J., Phillips, G. J., Reiffs, A., Parchatka, U., Pöhler, D., Lelieveld, J., and Crowley, J. N.: A two-channel thermal dissociation cavity ring-down spectrometer for the detection of ambient $\mathrm{NO}_{2}, \mathrm{RO}_{2} \mathrm{NO}_{2}$ and $\mathrm{RONO}_{2}$, Atmos. Meas. Tech., 9, 553-576, https://doi.org/10.5194/amt-9553-2016, 2016.

Thornton, J. A., Kercher, J. P., Riedel, T. P., Wagner, N. L., Cozic, J., Holloway, J. S., Dube, W. P., Wolfe, G. M., Quinn, P. K., Middlebrook, A. M., Alexander, B., and Brown, S. S.: A large atomic chlorine source inferred from midcontinental reactive nitrogen chemistry, Nature, 464, 271-274, https://doi.org/10.1038/nature08905, 2010.

Turnipseed, A. A., Huey, L. G., Nemitz, E., Stickel, R., Higgs, J., Tanner, D. J., Slusher, D. L., Sparks, J. P., Flocke, F., and Guenther, A.: Eddy covariance fluxes of peroxyacetyl nitrates (PANs) and NOy to a coniferous forest, J. Geophys. Res.-Atmos., 111, D09304, 2006.

Veres, P., Gilman, J. B., Roberts, J. M., Kuster, W. C., Warneke, C., Burling, I. R., and de Gouw, J.: Development and validation of a portable gas phase standard generation and calibration system for volatile organic compounds, Atmos. Meas. Tech., 3, 683-691, https://doi.org/10.5194/amt-3-683-2010, 2010.

Veres, P. R., Roberts, J. M., Wild, R. J., Edwards, P. M., Brown, S. S., Bates, T. S., Quinn, P. K., Johnson, J. E., Zamora, R. J., and de Gouw, J.: Peroxynitric acid $\left(\mathrm{HO}_{2} \mathrm{NO}_{2}\right)$ measurements during the UBWOS 2013 and 2014 studies using iodide ion chemical ionization mass spectrometry, Atmos. Chem. Phys., 15, 81018114, https://doi.org/10.5194/acp-15-8101-2015, 2015.

Wang, T., Tham, Y. J., Xue, L., Li, Q., Zha, Q., Wang, Z., Poon, S. C. N., Dube, W. P., Blake, D. R., Louie, P. K. K., Luk, C. W. Y., Tsui, W., and Brown, S. S.: Observations of nitryl chloride and modeling its source and effect on ozone in the planetary boundary layer of southern China, J. Geophys. Res.-Atmos., 121, 2476-2489, https://doi.org/10.1002/2015jd024556, 2016.

Wang, X. F., Wang, T., Xue, L. K., Nie, W., Xu, Z., Poon, S. C. N., and Wang, W. X.: Peroxyacetyl nitrate measurements by thermal dissociation-chemical ionization mass spectrometry in an urban environment: performance and characterizations, Front. Env. Sci. Eng., 11, 3, https://doi.org/10.1007/s11783-017-0925-7, 2017.

Warneck, P. and Zerbach, T.: Synthesis of peroxyacetyl nitrate in air by acetone photolysis, Environ. Sci. Technol., 26, 74-79, 1992.

Warneke, C., Trainer, M., de Gouw, J. A., Parrish, D. D., Fahey, D. W., Ravishankara, A. R., Middlebrook, A. M., Brock, C. A., Roberts, J. M., Brown, S. S., Neuman, J. A., Lerner, B. M., Lack, D., Law, D., Hübler, G., Pollack, I., Sjostedt, S., Ryerson, T. B., Gilman, J. B., Liao, J., Holloway, J., Peischl, J., Nowak, J. B., Aikin, K. C., Min, K.-E., Washenfelder, R. A., Graus, M. G., Richardson, M., Markovic, M. Z., Wagner, N. L., Welti, A., Veres, P. R., Edwards, P., Schwarz, J. P., Gordon, T., Dube, W. P., McKeen, S. A., Brioude, J., Ahmadov, R., Bougiatioti, A., Lin, J. J., Nenes, A., Wolfe, G. M., Hanisco, T. F., Lee, B. H., LopezHilfiker, F. D., Thornton, J. A., Keutsch, F. N., Kaiser, J., Mao, J., and Hatch, C. D.: Instrumentation and measurement strategy for the NOAA SENEX aircraft campaign as part of the Southeast Atmosphere Study 2013, Atmos. Meas. Tech., 9, 3063-3093, https://doi.org/10.5194/amt-9-3063-2016, 2016.
Wen, H., Hou, G. L., Huang, W., Govind, N., and Wang, X. B.: Photoelectron spectroscopy of higher bromine and iodine oxide anions: Electron affinities and electronic structures of $\mathrm{BrO}_{2,3}$ and $\mathrm{IO}_{2-4}$ radicals, J. Chem. Phys., 135, 184309, https://doi.org/10.1063/1.3658858, 2011.

Wolfe, G. M., Thornton, J. A., Yatavelli, R. L. N., McKay, M., Goldstein, A. H., LaFranchi, B., Min, K.-E., and Cohen, R. C.: Eddy covariance fluxes of acyl peroxy nitrates (PAN, PPN and MPAN) above a Ponderosa pine forest, Atmos. Chem. Phys., 9, 615-634, https://doi.org/10.5194/acp-9-615-2009, 2009.

Wollenhaupt, M., Carl, S. A., Horowitz, A., and Crowley, J. N.: Rate coefficients for reaction of $\mathrm{OH}$ with acetone between 202 and 395 K, J. Phys. Chem., 104, 2695-2705, 2000.

Zheng, J., Yang, D. S., Ma, Y., Chen, M. D., Cheng, J., Li, S. Z., and Wang, M.: Development of a new corona discharge based ion source for high resolution time-of-flight chemical ionization mass spectrometer to measure gaseous $\mathrm{H}_{2} \mathrm{SO}_{4}$ and aerosol sulfate, Atmos. Environ., 119, 167-173, https://doi.org/10.1016/j.atmosenv.2015.08.028, 2015.

Zheng, W., Flocke, F. M., Tyndall, G. S., Swanson, A., Orlando, J. J., Roberts, J. M., Huey, L. G., and Tanner, D. J.: Characterization of a thermal decomposition chemical ionization mass spectrometer for the measurement of peroxy acyl nitrates (PANs) in the atmosphere, Atmos. Chem. Phys., 11, 6529-6547, https://doi.org/10.5194/acp-11-6529-2011, 2011.

Zimmermann, S., Kippenberger, M., Schuster, G., and Crowley, J. N.: Adsorption isotherms for hydrogen chloride $(\mathrm{HCl})$ on ice surfaces between 190 and $220 \mathrm{~K}$, Phys. Chem. Chem. Phys., 18, 13799-13810, https://doi.org/10.1039/c6cp01962e, 2016. 